Portland State University

PDXScholar

Summer 8-16-2013

\title{
Modeling the Distribution of Bobcats and Areas of Reintroduction for Fisher in the Southern Washington Cascades
}

Shiloh Michael Halsey

Portland State University

Follow this and additional works at: https://pdxscholar.library.pdx.edu/open_access_etds

Part of the Animal Sciences Commons

Let us know how access to this document benefits you.

\section{Recommended Citation}

Halsey, Shiloh Michael, "Modeling the Distribution of Bobcats and Areas of Reintroduction for Fisher in the Southern Washington Cascades" (2013). Dissertations and Theses. Paper 996.

https://doi.org/10.15760/etd.996

This Thesis is brought to you for free and open access. It has been accepted for inclusion in Dissertations and Theses by an authorized administrator of PDXScholar. Please contact us if we can make this document more accessible: pdxscholar@pdx.edu. 
Modeling the Distribution of Bobcats and Areas of Reintroduction for Fisher in the Southern Washington Cascades

by

Shiloh Michael Halsey

A thesis submitted in partial fulfillment of the requirements for the degree of

Master of Science
in
Geography

Thesis Committee:

Martin Lafrenz, Chair

Robert Scheller

David Banis

Portland State University

2013 
(C) 2013 Shiloh Michael Halsey 


\begin{abstract}
The fisher (Martes pennanti) is a medium sized member of the mustelid family that once roamed the forests of Washington and whose historic range in the western United States once spread throughout the northern Rocky Mountains, the Cascade and Coast Ranges, and the Sierra Nevada (Carroll, Zielinski, and Noss 1999; Powell 1993, Spencer et al. 2011). Due to pressures from trapping and habitat fragmentation, the abundance of the species in the western United States has decreased dramatically and is thought to be limited to several small, isolated populations. In 2008, fishers were reintroduced to the Olympic Peninsula; however, bobcat (Lynx rufus) predation in the first years is thought to have killed off a significant portion of the released fisher hindering their ability to establish a selfsustaining population (Lewis et al. 2011). Other studies in the western United States have shown that bobcats can be a dramatic force on small or isolated fisher populations. The coniferous forest of the southern Washington Cascades is the possible site of a release of currently extirpated fishers. My research examines the distribution of bobcats in the region and explores the implication this and the habitat variables of the area have for a future reintroduction of fisher. By highlighting areas of high quality fisher habitat and low bobcat probability, the transplanted fishers will have an improved chance to forge home ranges and adapt to a new habitat in the early years with a decreased pressure of their most prominent predator.
\end{abstract}


The workflow of the research was a stepwise process of: 1) surveying forested areas in the southern Washington Cascades for the presence and absence of bobcat and acquiring previously completed survey data 2) using a classification tree to model the correlation of bobcat presence or absence with forest variables and 3) applying these relationships to a spatial analysis and the creation of maps showing areas of high ranking fisher habitat. The classification tree modeled the correlation between the forest variables and the results of the surveys, which included 145 bobcat absence observations and 39 presence observations. The model highlighted a $95 \%$ probability of absence above $1,303 \mathrm{~m}$ in elevation, $73 \%$ probability of absence in areas under 1,303 $\mathrm{m}$ in elevation and with a tree diameter value under $43.45 \mathrm{~cm}, 57 \%$ probability of absence in areas between $1,070 \mathrm{~m}$ and $1,303 \mathrm{~m}$ in elevation and with a tree diameter value above $43.45 \mathrm{~cm}$, and an $89 \%$ probability of bobcat presence in areas under 1,070 $\mathrm{m}$ in elevation with a tree diameter value above $43.45 \mathrm{~cm}$. I applied an upper elevation limit of 1,676 meters as a threshold for suitable habitat and only considered habitat suitable in cells with a tree diameter above $29 \mathrm{~cm}$. The three locations highlighted as the most suitable areas for reintroduction due to a large amount of the highest ranking habitat and the largest aggregations of suitable habitat cells were around the William 0. Douglas Wilderness that straddles the border of the Gifford Pinchot National Forest (GPNF) and the Wenatchee National Forest, another location in the Norse Peak Wilderness northeast of Mount Rainier, and a third location in Indian Heaven Wilderness in the southern portion of the GPNF. 


\section{Acknowledgements}

Various people, agencies, and organizations have assisted me in the completion of this research. Special thanks to Robert Scheller for his early support of the project and continued guidance throughout the research. Special thanks also to the Gifford Pinchot Task Force for funding much of the work and supplying the equipment needed to carry out the camera surveys. The survey data from the National Parks Service and the Cascades Carnivore Project were an invaluable addition to the study. Field assistance was provided by Cameron Jones, Jonathan Fain, Robert Scheller, Alida Halsey, and Tiffany Severson. Keith Hadley was instrumental in the editing of the research proposal, and the Dynamic Ecosystems and Landscapes Lab was continually generous with timely insights and recommendations. Thanks to William Zielinski, Roger Powell, and Jeffrey Lewis for publishing so many great papers on fishers, and to Greta Wengert for valuable information about bobcat and fisher dynamics in California. And finally, special thanks to Martin Lafrenz and David Banis for helping to solidify the final stages of the project. 
Table of Contents

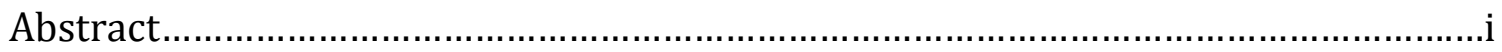

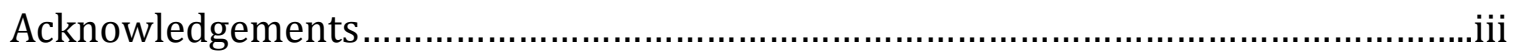

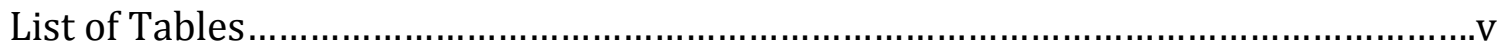

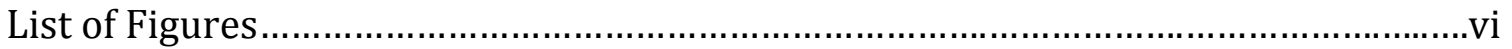

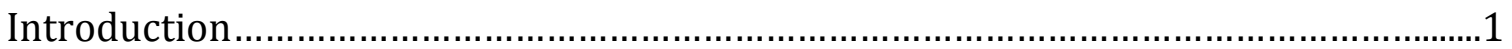

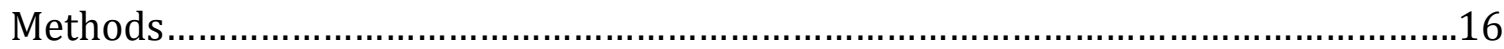

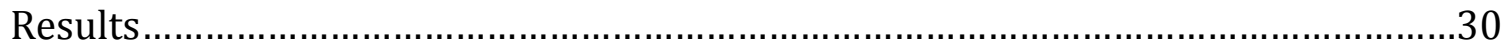

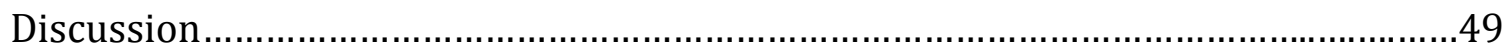

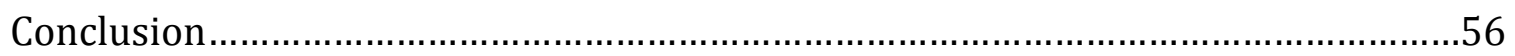

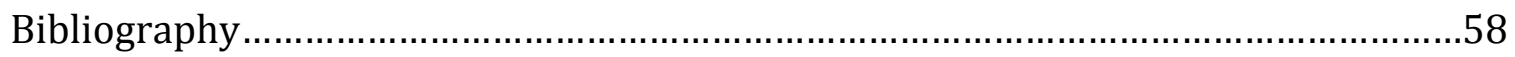

Appendix: Wildlife camera survey photographs .................................................68 
List of Tables

Table 1. Averages and coefficients of variation of raster cells inside the presence

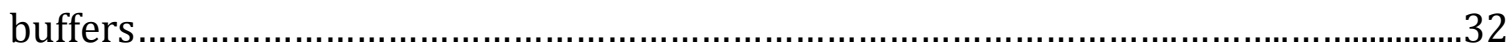

Table 2. Cross-validation of the survey data using $80 \%$ of the data to run the model and $20 \%$ of the data to measure the percentage of correctly predicted values..........34

Table 3. Cross-validation of the survey data using $85 \%$ of the data to run the model and $15 \%$ of the data to measure the percentage of correctly predicted values...........35 


\section{List of Figures}

Figure 1. Map of the study area and the presence and absence observations of the

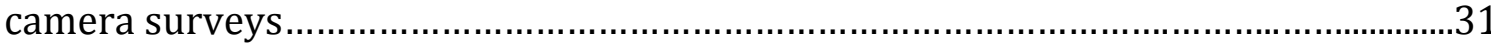

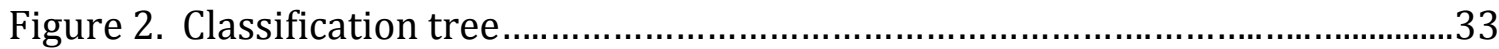

Figure 3. Schematic diagram of the research work flow from model output to map

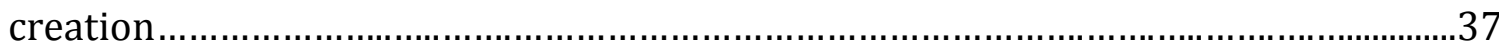

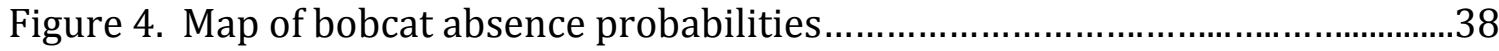

Figure 5. Map of potential fisher habitat before the integration of the bobcat

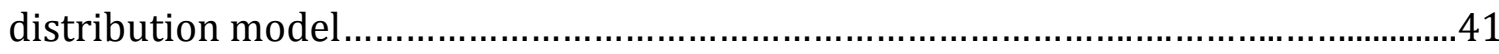

Figure 6. Primary map of ranked fisher habitat................................................44

Figure 7. Map of densely aggregated fisher habitat cells ....................................45

Figure 8. Map of ranked habitat with a lowered elevation limit of $1,524 \mathrm{~m} \ldots \ldots \ldots \ldots \ldots . . . .46$

Figure 9. Map of densely aggregated fisher habitat cells with a lowered elevation

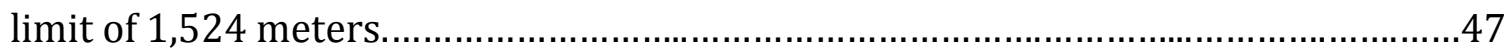

Figure 10. Map highlighting the three densest areas of high ranking fisher habitat

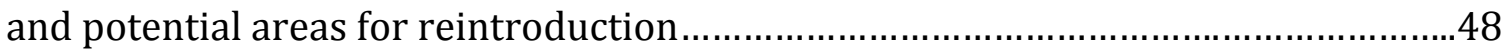




\section{Introduction}

The coniferous forest of the southern Washington Cascades is the possible site of a release of currently extirpated fishers (Martes pennanti) to an area of their native occupancy. My research examines the distribution of bobcats (Lynx rufus) in the southern Washington Cascades and explores the implication this and the habitat variables of the region have for a future reintroduction of fisher to the region.

Reintroductions are an effective way to re-establish fishers that have been extirpated from their native forests, but various populations and reintroduced groups of this sensitive species have been shown to be particularly vulnerable to bobcat predation (Ewen 2012; Lewis, Powell, and Zielinski 2012). The distribution of bobcats in the Pacific Northwest is not well understood and is not only an important piece in constructing comprehensive forest and wildlife management, it is an integral step in building an effective habitat analysis for fishers. My research is intended to strengthen a future reintroduction of fishers to the region by creating a full scale habitat suitability analysis integrating known biotic and abiotic habitat variables, including a model of bobcat distribution, to locate areas of high quality forest habitat where bobcat numbers are thought to be relatively low. By highlighting areas of high quality fisher habitat and low bobcat probability, the transplanted fisher population will have an improved chance to forge home ranges and adapt to a new habitat in the early years with a decreased pressure of its most

prominent predator. While fishers will inevitably come to face the effects of bobcat 
predation as they expand from their release sites and disperse throughout the landscape, my work attempts to minimize this potentially significant pressure in the early years, thereby increasing their ability to survive to reproduction and beyond.

My research builds upon the work of the Washington Department of Fish and Wildlife's feasibility assessment for the reintroduction of fishers to the state of Washington. In this research, the southern Washington Cascades was highlighted as a possible area for the reintroduction of fisher, along with the Olympic Peninsula and the North Cascades. The Olympic Peninsula had the largest amount and most contiguous array of potential fisher habitat and was therefore chosen as the first site for the reintroduction of fishers to Washington State (releases occurring 2008, 2009, and 2010). My research works off the assumption that the southern Washington Cascades has sufficient habitat to support a population of fishers and adds to this by analyzing small-scale variables and finding distinct areas within the region that have high ranking habitat and a density of suitable fisher habitat cells.

The fisher is a medium sized member of the mustelid family that once roamed the forest of Washington and whose historic range in the western United States once spread throughout the northern Rocky Mountains, the Cascade and Coast Ranges, and the Sierra Nevada (Carroll, Zielinski, and Noss 1999; Spencer et al. 2011). Due to pressures from trapping and habitat fragmentation, the abundance of the species in the western United States has decreased dramatically and is thought to be limited to several small, isolated populations in the Siskiyou 
Mountains of southern Oregon, the northwestern mountains of California, and in the southern Sierra Nevada in central California (Aubry and Lewis 2003; Ingram 1973). Trapping regulations in the state of Washington were initiated in the 1933, but the imperiled populations had already suffered a loss in numbers; statewide surveys from 1989-2000 failed to detect the presence of fishers (Lewis and Hayes 2004).

In 2008, fishers were reintroduced to the Olympic Peninsula; however, bobcat predation in the first years is thought to have killed off a significant portion of the released fisher hindering their ability to establish a self-sustaining population (Lewis et al. 2011). Reintroduced fishers are vulnerable to bobcat predation as they establish home ranges and try to adapt to new surroundings. A large amount of time, money, and resources go into a reintroduction effort, and careful planning is needed to ensure that as many fishers as possible are able to survive to reproduction and beyond. Bobcat and fisher studies in the Hoopa Indian Reservation have shown that bobcat predation is a significant factor in the survivorship of local fisher populations (Callas and Figura 2008; Higley and Matthews 2006). Research conducted through the Sierra Nevada Adaptive Management Project has recently highlighted bobcat predation as a major force of mortality on that small native population (R. Sweitzer, unpubl. data). A comprehensive study of several California populations attributed $77 \%$ of female fisher mortality to bobcat predation (G. Wengert, UC Davis, unpubl. data). In Wisconsin, Gilbert (2000) has found that fishers shift their diets in areas of high bobcat densities. As more research uncovers the intricacies of this species 
interaction, the impact that bobcat predation has on fisher populations becomes more clear in its role in affecting population dynamics for groups of fishers, particularly for isolated or nascent groups.

Fisher biology and historical context

Fishers are habitat specialists requiring dense, multi-story canopy in low to mid-elevation forests (Allen 1983; Scheller et al. 2011; Jacobson, Lewis, and Snyder 2003). High cavities in large-diameter snags or live trees provide natal dens for fisher kits, which are born bald and blind in late March (Powell 1993). After two months, the kits are moved to maternal dens located in lower structures, such as hollow logs or root wads. In addition to these den components, adult fishers use a variety of diverse forest structures for resting sites that serve as protection from predators and are useful for thermal regulation. A thick understory density helps maintain important habitat components while also providing a home to an array of prey species. Fishers are opportunistic predators that eat a wide variety of rodents and small mammals including, but not limited to snowshoe hares, gray squirrels, flying squirrels, voles, mice, shrews, grouse, lizards, and even fruits, nuts, and seeds (Zielinski and Duncan 2004; Gilbert 2000). In addition, they are one of the few species that confront the task of attacking porcupine for a meal. Fishers are dietary generalists and are able to alter the makeup of their diet depending on location, elevation, competing interaction, and the availability of prey. A variety of squirrels 
are thought to be abundant in the southern Washington Cascades and records indicate the existence of mountain beaver and porcupine populations in low elevation areas (Buchanan, Lundquist, and Aubry 2013). The average home range of a female fisher is around $10 \mathrm{~km}^{2}$, while the home range of a male fisher is often twice that (Davis, Seo, and Zielinski 2007; Zielinski et al. 2004). Habitat area estimates required to sustain viable fisher populations are around $260 \mathrm{~km}^{2}$ (Allen 1983).

Populations of fishers in the western states suffered heavily from overtrapping and habitat loss in the early part of the century, and as a species with low reproductive rates, poor dispersal, and naturally low densities, recovery from these pressures was not possible in many areas (Powell 1993). Trapping was widespread in the late 1800 s and early 1900s, and is thought to be the main reason that led to the extirpation of fisher in many regions of the west. Trapping regulations were initiated in Oregon in 1913 to limit trapping to the winter months and to require the reporting of fishers trapped, but by that time, fisher populations were on a rapid downward trajectory. By the late 1920s, the number of fishers trapped annually in Oregon had dropped to an average of eight per year in spite of sustained trapping effort (Aubry and Lewis 2003). A similar decline in harvest yield was seen in Washington where trapping went unregulated until 1933 when the newly created Washington Department of Fish and Game prohibited the trapping of fishers (Aubry and Houston 1992). Records of harvest yields suggest that fisher populations were already dangerously low in Washington by this point. California and Oregon 
followed suit with a complete restriction of fisher trapping in 1937 and 1946, respectively (Aubry and Lewis 2003). Incidental poisoning from strychnine baits designed to kill wolves and coyotes has been cited as another possible factor, which in conjunction with trapping and habitat loss, severely lowered population numbers throughout the western United States. In contrast to the fate of fishers in the west, fisher populations in the eastern part of the country are robust; it should be noted, however, that the eastern populations are genetically different from the native fishers in the west (Powell 1993; Aubry and Lewis 2003).

Due to the dwindling population sizes, three petitions have been filed to list western populations of fishers as threatened under the Endangered Species Act (Vinkey et al. 2006). Petitions in 1990 and 1994 to list the fisher populations in the Pacific states as federally endangered and threatened were rejected. (Aubry and Lewis 2003). In 2004, the U.S Fish and Wildlife Service responded to a third petition by stating that listing the species as threatened in Washington, Oregon, and California was "warranted but precluded" because of higher priority actions, which placed the fisher on something akin to a waiting list (Lewis et al. 2011; Vinkey et al. 2006). The difficulty in actually listing the fisher as threatened or endangered is due to a lack of conclusive evidence verifying their absence, especially in the face of reported sightings from trappers and forest recreationalists, and also due to a debate as to whether west coast fishers are a distinct population segment or a distinct subspecies, which had been questioned due to unknown genetic variances and suggested connections to habitats and populations in Canada (Aubry and Lewis 
2003; Vinkey et al. 2006). Presently, the fisher is listed as an endangered species in Washington and is a candidate species for listing as endangered in the Pacific states (Lewis, Powell, and Zielinski 2012).

In an effort to more fully understand the status of fisher populations in the west, surveys were conducted by state and federal agencies to search for presentday existence in areas where observations and historical records suggested their presence. These surveys were carried out from 1989 to 2000 and employed motion triggered cameras and sooted track plate boxes. No fishers were detected in the state of Washington and many of the sites in Oregon and California where occurrence records suggested presence, were also void of fisher detections (Aubry and Lewis 2003). Two populations were found in Oregon in the southern portion of the state. It was determined that the group of fishers in the Siskiyou Mountains southwest of Ashland was a native population while the other group, located near Klamath Falls in the southern Oregon Cascades, was descended from a reintroduction that occurred 20 years prior. Surveys in California uncovered a native population in the coastal and inland mountain ranges of northwestern California as well as in the southern part of the Sierra Nevada near Yosemite National Park. 
Fisher reintroductions:

There have been reintroductions in various western states over the last century to re-establish fishers to areas of their native occupancy so that the continuation of the species can be supported through connectivity and the existence of adequately large tracts of continuous habitat. The fisher has been cited as one of the most successfully reintroduced carnivores in North America, although much of this success has been from reintroductions in the eastern United States (Powell 1993; Lewis, Powell, and Zielinski 2012). Reintroductions in Oregon were initiated in the 1961 to help quell the unusually large porcupine (Erethizon dorsatum) populations that were causing damage to the timber products in the area. Prompted by Weyerhaeuser and the Forest Service, the Oregon State Game Commission reintroduced 11 British Columbia fishers near Klamath Falls and 13 to the Wallowa Mountains near La Grande (Ingram 1973). Between 1977 and 1981 more fishers were introduced to this southern Oregon location using animals from British Columbia (17) and from Minnesota (13). Little to no effort was made to monitor these introduced groups and the details of their existence or dispersal remain a mystery. Recently, DNA and morphologic analysis was used to link the Klamath population to the translocated animals from Minnesota (Vinkey et al. 2006). This group of fishers has a larger body size and is genetically unique from the native group of fishers in the Siskiyou Mountains of Oregon. The two populations remain mostly separated by the I-5 corridor, urban and agricultural development, and the oak savannahs of the region (Clayton and Kienast 2008). 
Releases in the west have also taken place in Montana and Idaho where, from 1959 to 1963,75 fishers were released into the forest for purposes of porcupine control and to re-establish the species in the region (Aubry and Lewis 2003). At the time it was not known, but there was already an extant native population of fishers in part of western Montana (Lewis, Powell, and Zielinski 2012). A more recent reintroduction effort took place in Montana from 1989 to 1991 where another 110 fishers were released (Vinkey et al. 2006). Populations in Idaho and Montana, presumably with the help of these release efforts, are thought to be healthy at this time.

There has been one known release of fishers in California, and this took place from 2009 to 2011 in the Stirling Management Area in Northern Sierra Nevada east of Redding. Forty fishers from the native population in northwestern California were released into the forests here; active monitoring and research has followed this group throughout the process and determined that the fishers are successfully reproducing and establishing home ranges. Six of the forty fishers have died since the release effort. Bobcat predation was found to be the cause of mortality for two of the individuals, drowning accounted for one, vehicle collision was responsible for one, and the cause of mortality for the other two is unknown (Powell, Facka, and Clifford 2012).

The only reintroduction effort in Washington occurred over a three year period in 2008, 2009, and 2010, and consisted of the translocation of 90 fishers 
from British Columbia to various locations in the Olympic National Park (Lewis, Powell, and Zielinski 2012). This cooperative effort was carried out through a partnership of the National Park Service, The Washington Department of Fish and Wildlife, United States Geological Survey, and Conservation Northwest. In year one 18 fishers were released, 31 in year two, and 41 in year three; all individuals were fitted with radio collars. The results from this monitoring effort documented mortality rates, population patterns, and the movements of individuals. Predation was the most common cause of mortality followed by vehicle collisions. The causes of death were as follows: unknown $27 \%$, predation $23 \%$, unknown but predation probable 20\%, vehicle strikes 20\%, drowning 7\%, trapping related 3\% (Lewis et al. 2011). This breakdown highlights predation as a probable factor responsible for at least $43 \%$ of the mortalities, with the possibility that many of the miscellaneous unknown mortalities could be attributed to predation as well. Although species identification of the predator is not usually known, the two verified predation deaths were attributed to bobcat. Motion triggered cameras were set up at several locations to determine if kits had been born following reintroduction. One camera captured a bobcat climbing up to the natal den of a female fisher that was eventually found to have been killed by a bobcat in separate location. Although the cause of mortality for half of the fishers that died is unknown, bobcat predation could be a likely cause considering the known existence of bobcats in the Olympic Peninsula and the results of other research showing the potentially significant effects that bobcat predation has been shown to have. 
Bobcat biology and historical context

The bobcat is a wide-ranging and elusive carnivore found throughout the forests and plains of North America. The bobcat's northern limit loosely follows the United States - Canada border, where its close relative, the Canada Lynx, abounds. As a habitat generalist, the bobcat is able to survive in disparate parts of the continent from the fragmented landscapes of New England to the coniferous forests of the Pacific Northwest. Found in every state in the U.S. except Delaware, Alaska, and Hawaii, bobcats are the most widely distributed cat species in North America (Hanson 2007). Even in these varied regions of existence, certain types and levels of habitat variables are needed to ensure the survival of local populations. Their crepuscular nature brings them out at dawn and dusk to hunt and roam, an adaptation that aligns their activity with that of their prey. Although their diets are regionally specific, there are certain items regularly found in studies of bobcat: cottontail rabbit, snowshoe hare, mouse, bird, muskrat, squirrel, and white-tailed deer (Koehler et al. 1991; Blankenship et al. 2006).

Males have large home ranges that often overlap with several female home ranges. This allows males the opportunity to mate with various females, and the allopatric spatial arrangement of male home ranges lessens aggressive interactions between competing males (Donovan et al. 2012; Benson, Chamberlain, and Leopold 2004). Home range estimates for bobcats vary by region with large home ranges often found in areas of lower habitat quality and lower prey density. Scientists 
studying a bobcat population in Northern California found home ranges of females averaging $14.4 \mathrm{~km}^{2}$ and males $57.6 \mathrm{~km}^{2}$ (G. Wengert, UC Davis, unpubl. data). An analysis of Wisconsin bobcats highlighted a mean home range size of $69 \mathrm{~km}^{2}$ for males and $28 \mathrm{~km}^{2}$ for females in the Chequamegon National Forest and $41 \mathrm{~km}^{2}$ and $31 \mathrm{~km}^{2}$ in the St. Croix National Riverway (Gilbert 2000). A 1971 study of bobcats in Washington found home ranges of 6.5 to $15.5 \mathrm{~km}^{2}$ for males and 3.9 to $8.4 \mathrm{~km}^{2}$ for females (Knick, Brittell, and Sweeney 1985). And, a unique study from Koehler in Idaho, found that bobcat home ranges varied by season, with home ranges averaging $23 \mathrm{~km}^{2}$ in summer and $88 \mathrm{~km}^{2}$ in winter (Koehler and Hornocker 1989). This seasonal variation is most likely driven by prey availability and the necessity of distant travel in months with lower prey densities and higher amounts of snow, which is a factor that strains the search and acquisition of prey (Koehler et al. 1991; Koehler and Hornocker 1989).

Although habitat variations exist within the broad array of regions that bobcats are found, there are certain habitat variables that are vital for a local population's continued survival. As was seen in the Midwestern states during the period of rapid agricultural growth in the early part of the century, local bobcat populations can drop and disappear when adequate habitat variables are not available (Tucker, Clark, and Gosselink 2008). Tree cover is an important habitat requirement and is needed for stalking prey and evading predators. In spring, when a pregnant female senses that her kittens are soon to be born, fine scale habitat factors rise in importance. Refuge in a cave or a hollow log, under a rock ledge, a 
brush pile, or the upturned roots of a downed tree will help ensure protection from predators such as mountain lions, foxes, owls, coyotes, other bobcats, and humans (Hanson 2007). These areas also serve as protection from heavy rain and hot sun.

Bobcats in North America have undergone numerous population swings through the last century as habitat modification and harvesting pressures have waxed and waned. Bobcats in Illinois suffered a major drop in numbers and were listed as a threatened species in 1977 (Nielsen and Woolf 2003; Mcdonald et al. 2008). The annual harvest of bobcat pelts in New Hampshire went from 421 in 1959 to only 10 in 1970 despite continued harvesting effort; this prompted the state to designate the bobcat as a protected species in 1989 (Litvaitis, Tash, and Stevens 2006). With the crash of the stock market in 1987 and the plummeting of the commercial fur market, bobcat populations began to rise back up. While a small resurgence in harvesting has been seen in the past decade, regulations are now in place to monitor harvest and to help prevent large crashes or local extinctions. Today's population numbers are thought to be healthy in most states and although research is scant in certain areas, wildlife agencies in many states have created networks with scientists, trappers, and hunters to get up-to-date inventories of the status of regional populations. Unfortunately, there has been very little work on bobcats in Washington. Knick et al. (1985) found bobcat densities in Washington of 1 per $5.5 \mathrm{~km}^{2}$, which is within the normal range. This study highlighted snowshoe hares and mountain beavers as their primary prey, but the work did not examine the role of habitat features in predicting bobcat presence or absence. 
Research focus

My research is intended to fill in this gap of knowledge and to help answer some of the unknown questions about bobcat-habitat relationships of the region. The work will tie this investigation into the planning of a reintroduction of fisher to Washington. My study began with camera surveys in the forests of southern Washington to determine presence or absence of bobcat. Survey data from this effort and from other sources employing similar survey methods was integrated with raster layers of forest data for the modeling process. Bobcat distributions were explored using a classification tree in R statistical software. The model supplied bobcat distribution probabilities that were used in conjunction with previously explored fisher habitat parameters as input data for the fisher habitat suitability analysis that was carried out in ArcGIS. The goal of the suitability analysis was to produce a spatial representation of potential fisher habitat showing areas with sufficient habitat components that also have a high likelihood of bobcat absence. This primary representation of fisher habitat was the main focus of the research and was used for the final interpretation and the recommendation of habitat areas for the next reintroduction of fisher. In addition, this cell-based layer was incorporated into the kernel density tool to highlight areas of densely aggregated high ranking habitat. A parallel analysis was also carried out using a lowered elevation threshold to create representations using two different approaches to habitat delineation as it relates to elevation. 
The hope of many conservationists is that fisher will be added to the list of mammals roaming the forests of the Washington Cascades and that we will see the return of this carnivore to the coniferous forests of the region. The return of the fisher to the southern Washington Cascades is unlikely without the help of reintroduction since no close populations of fisher exist that could serve as dispersal agents. Once fishers are established in the region, though, the connectivity of the region will allow future dispersal north into the farther reaches of Mount BakerSnoqualmie National Forest, Wenatchee National Forest, and the Northern Cascades. As climate change is likely to affect the climatic gradients of this region, making northerly expansion more plausible and maybe necessary, this linkage will become a valuable trait. Fishers and bobcats are both parts of the native fabric of Washington and as our understanding of how habitat features affect these species and how they may affect each other we can be in a better position to support their continued existence. 


\section{Methods}

Study Area

The southern Washington Cascades range is characterized by large tracts of coniferous forest and the volcanic peaks of Mount Rainier, Mount St. Helens, and Mount Adams. Douglas fir (Psuedotsuga menziesii), western hemlock (Tsuga heterophylla), red alder (Alnus rubra), bigleaf maple (Acer macrophyllum), and western red cedar (Thuja plicata) dominate the canopy on the western slopes of the Cascade Range where this research was focused. The forests of this region exist in varying stages of succession due to a history of logging and fires (Knick, Brittell, and Sweeney 1985). The 9,842 $\mathrm{km}^{2}$ study area encompasses the southern part of the Mt. Baker-Snoqualmie and Wenatchee National Forests (WNF) $\left(3351 \mathrm{~km}^{2}\right)$, all of Mount Rainier National Park (954 $\mathrm{km}^{2}$ ), and all of the Gifford Pinchot National Forest (GPNF) (5537 km²), which includes the Mount St. Helens National Volcanic Monument. The GPNF accounts for the majority of the study area and contains the greatest number of survey locations used for the research. Mount Rainier, rising to 4,392 meters, represents the highest elevation in the study area, and Mount St. Helens represents one of the most notable historical features of the region due to the massive eruption that occurred there in 1980. The region has meadows, wetlands, low and high elevation lakes, glaciers, second-growth forests, and oldgrowth stands that are over 1000 years old. The forests of the region are home to an array of mammals including black bear (Ursus americanus), cougar (Puma 
concolor), coyote (Canis latrans), fox (Vulpes vulpes), deer (Odocoileus hemionus), elk (Cervus canadensis), mountain goat (Oreamno americanus), snowshoe hare (Lepus americanus) and various rodents. A wolverine (Gulo gulo) was caught on camera on Mount Adams in 2009 and there has been recent evidence of a return of wolves (Canis lupus) to the area. Annual precipitation in the low-mid elevation areas hovers around 100 to $180 \mathrm{~cm}$, with an annual 150 to $250 \mathrm{~cm}$ of snow (Brockway et al. 1983). Management is mostly in the hands of the Forest Service and the National Park Service, but small tracts of privately owned land are also part of the mosaic of land management in the study area. In addition, there are numerous wilderness areas in the region. Highway 12 cuts east west through the northern portion of the GPNF and the southern part of the WNF. Highway 410, the only other two-lane highway in the study area, lies between the wilderness areas of Norse Peak and William 0. Douglas slightly north of Highway 12. These roadways carry heavy traffic on a daily basis, but are small enough that they don't represent dispersal barriers for most animals.

Surveys and data

The workflow of the research was a stepwise process of: 1) surveying forested areas in the southern Washington Cascades for the presence and absence of bobcat and acquiring previously completed survey data 2) modeling the correlation of bobcat presence or absence with forest variables and 3) applying these 
relationships to a spatial analysis of bobcat distribution and creating maps of ranked fisher habitat and densely aggregated habitat cells. Bobcat distributions were assembled using survey data obtained from three sources with each employing a similar survey method of baited, motion triggered camera sets on a 28-day survey duration. The methodology for all the camera surveys followed the general framework for non-invasive carnivore survey guidelines described by Zielinksi and Kucera (1995). Lure is used in many surveys as a long distance attractant and is usually a thick and powerfully scented liquid made from proprietary recipes created by fur trappers. Lure is intended to attract animals from a distance and then bait, usually raw chicken or deer, is used to bring photographic subjects directly in front of the camera. Bobcat home ranges remain relatively stable over years so the temporal spread of the surveys (2002-2013) was not expected to affect modeling (Benson, Chamberlain, and Leopold 2004). The National Park Service supplied results from camera surveys in Mount Rainier National Park from 2002 to 2004. These surveys were mainly intended to search for the presence of fisher populations in Washington; they collected data on a variety of animals, but only the bobcat presence and absence information was gleaned for this analysis. The Cascades Carnivore Project, a non-profit conservation organization exploring the existence of the rare Cascade red fox, supplied data from mostly high elevation areas of the Gifford Pinchot and Wenatchee National Forests, Mount Rainier National Park, and Mount St. Helens National Volcanic Monument. These surveys, spanning from 2009 to 2013 , collected carnivore detection data mainly in areas above 1000 meters. 
I collected regionally specific data throughout the GPNF from June to November 2012 with survey equipment and funding supplied by the Gifford Pinchot Task Force. The sites that I surveyed were delineated by a random generation of points through ArcGIS with a minimum of $4 \mathrm{~km}$ between points. A minimum distance was established to lessen the probability that an individual bobcat would be photographed at more than one site. Every effort was made to get as close to the actual survey points as logistically feasible considering safety and accessibility using paved, gravel, and dirt roadways and hiking within 1-2 kilometers of the road. There was a maximum of $1.5 \mathrm{~km}$ between selected and actual locations and if it was unfeasible to get this close, the site was dropped from the analysis. One camera was employed at each site and set to take a rapid succession of photos when a motion was detected. Each camera was in operation for at least 27 days (with an average survey duration greater than 28 days); the cameras were checked every two weeks. When visiting each camera, the bait and lure were reloaded and any photos taken were uploaded. Raw chicken was used as localized bait and either Gusto brand or Halseth's bobcat specific lure was used to attract animals from long distances. Each location was given a delineation of presence or absence; a simple presence is obtained even if more than one bobcat was seen. Data tables consisting of site number, presence or absence, and the GPS coordinates were imported into ArcGIS as points.

To get a measure of the forest composition in the closely surrounding areas beyond the particular point feature, 100-meter radius buffers were created and 
used for rest of the bobcat distribution modeling instead of the point location. The forest values inside the 100-meter buffer were used to analyze the relationship of forest composition to presence or absence of bobcat. The forest data layers used for the bobcat distribution modeling, as well as for the final fisher habitat suitability analysis, were acquired from Landscape Ecology, Modeling, Mapping and Analysis (Ohmann and Gregory 2002). The data is derived from a gradient nearest neighbor approach, which uses a multivariate gradient analysis linking field plot data, satellite imagery, and maps of environmental variables to create a raster grid of large ecoregions in California, Oregon, and Washington (Ohmann and Gregory 2002). This raster data was delivered in a 30 meter resolution. The predictor variables from LEMMA chosen for the bobcat distribution analysis are forest dynamics variables that often serve as indicators of quality habitat for other mammals in the western United States and which could potentially serve as predictors for bobcat presence: canopy cover percentage, percentage of coniferous canopy cover, quadratic mean diameter of trees (dbh), and basal area of coniferous trees $>2.5 \mathrm{~cm}$ in diameter. Two different measures of conifer existence were included to test if one had better predictive value than the other. Elevation was the fifth variable and was derived from a general digital elevation model layer provided by the United States Geological Survey (USGS).

The zonal statistics tool in ArcGIS was used to average the forest values of all the raster cells contained within the 100 meter buffer. Each buffer had about 35 raster cells that were to be averaged; this was done separately for each of the forest 
variables and separately for presence and absence buffers. The tables created by running zonal statistics for presence and absence buffers on each raster layer were compiled together using the join table tool in ArcGIS. In addition to calculating averages, standard deviations were calculated for each bobcat presence buffer to quantify the variance within each of the presence buffer. This coefficient of variation was calculated to examine whether correlation may have been offset by large degrees of within buffer variance. A large measure of within buffer variance would lessen the degree to which the classification tree is modeling the representative values within each buffer. For instance, if a buffer has a large variance and is filled with cell values of mainly zero and 100, the model would misapply correlation when it models an average of 50 for that buffer.

\section{Classification tree}

A classification tree was built for this analysis using the 'rpart' package in $\mathrm{R}$ statistical software in order to determine the relationship between the presence and absence of bobcat to the predictor variables of canopy cover, canopy cover of conifers, quadratic mean diameter, basal area of conifers $>2.5 \mathrm{~cm}$, and elevation. Classification trees are useful analysis tools for ecological data because they are flexible, do not assume normal distributions, and can deal with non-linear relationships (Baker et al. 2006; De’ath and Fabricius 2000; Muñoz and Felicísimo 2004). A classification tree functions by highlighting variation of a response 
variable and splitting the data, stepwise, into more homogeneous groups. As the classification process splits the data according to correlation between predictor and response variables and finds the lowest variance in predictor values, the data is partitioned into two groups. This procedure is then carried out for each resulting group until the tree is fully built; this is the point at which groups have been divided to a point of relative homogeneity as determined by the model (De'ath and Fabricius 2000). The splitting of the variables is conditional and the models are run stepwise; the top variable is the most important and each subsequent variable is only utilized after making a yes or no decision at the previous node. The groups are organized by an expected value of the response variable and each branch is defined by this dominant category, presence or absence. For each split there is an indicator showing the value at which a certain predictor variable was split and a branch showing the number of presence and absence observations on either side. For instance, if the split determines that presence is highly correlated with canopy cover above $80 \%$, the node that represents that has a display showing $>80 \%$, and branches on either side show the expected category and how many presences and absences were found on either side of this split.

A process of sub-setting the data for cross validation is common for large data sets being modeled in classification trees. Due to the small sample size of this study, the final model does not use a cropped data set; however this procedure was carried out to determine the validity of the model. Twenty different subsets were 
created (ten with divisions of $80 \% / 20 \%$ and ten with divisions of $85 \% / 15 \%$ ) and modeled; a cross-validation table was created for each subset.

\section{Reclassification}

Habitat variables most associated with bobcat presence and absence had been determined and were used to create division points in the reclassification of the raster lookup table layers. The nodes in the final tree, showing which variables are split at what break points, were used as the input data for the reclassification of raster layers in ArcGIS. The reclassification tool was used to separate the levels of the variables according to likelihood of presence or absence. Fisher habitat data was used to further classify these layers so they would then represent a combination of model results and fisher habitat parameters. Raster calculator summed overlapping cells of the different variable layers to determine which spatial locations had summed totals that represented certain ranks of fisher habitat suitability according to both fisher habitat parameters and the results of the bobcat distribution model. This layer was then combined with any fisher habitat variables that had not already been reclassified with the bobcat model results. 
Habitat suitability map

The fisher habitat suitability map was constructed using the layer that had been created by combining the bobcat distribution model results and fisher habitat parameters of the same variables with a raster layer of canopy cover obtained from LEMMA; the canopy layer was reclassified to 0 for $0-60 \%$ canopy cover and 10 for $60-100 \%$ canopy cover. Canopy cover and the variables of tree diameter and elevation previously integrated into the bobcat distribution layer were weighted for the fisher habitat suitability analysis according to fisher habitat data from studies in the western states and from habitat models developed to examine various environmental variables.

Elevation is a strong fisher habitat determinant due to its effect on snow cover and tree density at higher elevations. The scarcity of trees produces a lack of suitable protection from snow and cold, and a dearth of available prey. In the Northern Sierra Mountains of California, the majority of fishers found in a regional habitat study were observed in areas with an average elevation of 1,676 meters (Allen 83). Lewis and Stinson (1998) found that historical records of fishers in Washington were not found above 1800 meters and were most common under 1000 meters, however, the latter finding might be biased because of a lack of observations in areas with deep snow. In the feasibility assessment created for the first Washington reintroduction, areas below the upper limit of the silver fir zone (around 2,000 meters in the southern Washington Cascades) were designated as 
suitable for a reintroduction. Working from the suggestions of the preceding feasibility assessment and its authors, the upper limit of suitable habitat for the fisher habitat suitability analysis was set at 1,676 meters. To be sure that an elevation threshold of 1,676 meters did not extended above the upper line of the silver fir zone, I calculated the average basal area of silver fir for all cells at this elevation gradient in the study area. In this manner I was able to verify that relatively dense aggregations of silver fir forest cells were still present at and above my upper threshold (silver fir data were obtained from LEMMA). Another iteration of the reclassification and density application process was carried out to show areas of suitable habitat with an upper limit set to a lower threshold of 1,524 meters. This rendering of habitat potential was completed to add to the overall utility of the research by creating an alternate and more conservative version of the analysis and to help underscore the role that differing levels of elevation offer to the aggregation of suitable habitat.

Canopy cover is a strong determinant of fisher habitat as it is a factor in limiting snow depth in the winter months and is linked with suitable prey abundances (Ingram 1973; Lewis et al. 2011; Powell 1993). Deep snow cover makes survival more difficult for fishers by increasing their energy expenditure and hindering their ability to find food (Aubry and Houston 1992). Raine found that fishers adjust from a simple gallop to a more energy expensive bounding gait in snow covers above $8.1 \mathrm{~cm}$ (Krohn, Elowe, and Boone 1995). Allen (1983) created a habitat index for fishers based on empirical studies of the species and noted that 
fishers confined their activity to forested cover types when the snow level was above $4-5 \mathrm{~cm}$. Allen's index suggests a predicted absence of fisher habitat in areas with a canopy cover $<40 \%$. The suitability index rises sharply starting at $40 \%$ and peaks then plateaus around 80\% canopy cover (Allen 1983). A habitat model created by Zielinski et al. (2004) from a population of fishers in the Sierra Nevada Mountains of California showed that the largest mean proportion area of fisher home ranges (66.3\%) occurred in stands with a closure of 60-100\%. Buck et al. (1979) studied fishers in northwestern California and found that a canopy cover between 40-70\% was supporting a reproducing population of fishers. To avoid an overestimation of habitat, I designated cells with a canopy closure $>60 \%$ as suitable for fisher habitat.

Large diameter trees are vital for the raising of young fisher kits and it is the cavities within these trees where fishers keep the very young until they are old enough to be moved to lower dens on the forest floor where they eventually begin to use down trees, upturned roots, and fallen snags ( Powell 1993; Zielinski et al. 2004). Fisher kits are born blind and bald and require a natal nest of a hollow snag or rotted out tree with a hole to serve as protection from the temperature extremes, predators, and male fishers. Wide trees commonly offer other structural qualities such as lateral limbs, pockets of decay, and mistletoe brooms that serve other site level values for fisher as rest sites and maternal dens (Callas and Figura 2008). Large diameter trees are also indicators of old-growth, where the understory composition is likely to be diverse, multi-tiered and able to support larger numbers 
of small prey (Aubry and Houston 1992). While young forests can sometimes contain a relatively large diversity of rodents and snowshoe hares, old-growth in Washington is more likely to support higher abundances of Douglas' squirrels, voles, mountain beavers, and small forest-floor mammals (Carey et al. 1995; Stinson and Lewis 1998; Lewis and Hayes 2004). Zielinski et al. (2004) found that the highest proportion area of fisher home ranges $(60.7 \%)$ in the Sierra Nevada were in areas with moderately sized trees $(29-61 \mathrm{~cm})$ rather than areas of predominantly small or large to very large trees. This minimum metric $(29 \mathrm{~cm})$ was used as minimum value in my analysis; any cells under this value were considered non-suitable for fisher. Various studies have shown that fishers often seek out the largest trees in an area and that the stand level tree size parameters are less strict provided that some large trees are present on the landscape. Aubry and Raley (2006) found that small quantities of certain fisher habitat elements, mainly trees with a large diameter, seemed to be ample for the sustaining of fisher populations since fishers generally seek these components out in the scope of the broader area. They did, however, find that canopy cover near and closely surrounding fisher den sites was $\geq 80 \%$ compared to the $67 \%$ canopy cover found at randomly sampled locations within their study area suggesting that stand level canopy cover characteristics would likely have relatively high value in a reintroduction analysis (Aubry and Raley 2006). I used a minimum of $29 \mathrm{~cm}$ with the hope of finding areas that were not recently logged and that had the potential for containing a moderate amount of medium to wide trees and a certain degree of structural diversity. 
Conifer cover is an important component for fisher habitat because the evergreen leaf cover serves as protection from deep snow accumulations on the forest floor. For the fisher habitat suitability analysis, conifer cover was assumed in the measure of canopy cover because the study area is a predominantly coniferous forest. A majority conifer proportion is requisite to be quality fisher habitat, although a small hardwood component can be important since hardwoods are more likely to suffer heart rot and internal decay, thereby offering opportunities for females to make natal dens (Powell 1993). Hardwoods of the Pacific Northwest rot and form cavities at a younger age and smaller size than conifers of the area (Callas and Figura 2008). Fishers tend to avoid establishing home ranges in areas with no hardwood species, yet a low proportion of hardwoods is suffice since the function of serving as a natal den is the main role these types of trees serve for fishers (Lewis and Hayes 2004).

The ranking of fisher habitat was estimated by overlaying the layer that had combined the model results and associated fisher habitat parameters with the canopy cover layer and summing them with raster calculator. The fisher habitat thresholds in the first layer were applied to tree diameter (only using cells with a QMDA value $>29 \mathrm{~cm}$ ) and elevation (only using cells with a DEM value $<1,676 \mathrm{~m}$ ). The raster layers were reclassified and stacked according to the likelihood of bobcat presence and absence and all the designated fisher habitat parameters to create a map with according levels of rank. This cell-based representation was used as the primary map for interpreting potential areas of reintroduction where the level of 
bobcat probability could be taken into consideration with confidence that the fisher habitat components were ample in that particular spatial cell. Also, a kernel density function was applied to this final raster layer in order to highlight areas with densely aggregated cells of high ranking habitat. This rendering allowed release locations to be graphically displayed and compared more easily on the scale of the study area. A search radius of 3,534 meters was used to calculate density within the kernel density tool so that this function would only count cells within the diameter of an average female fisher home range of $9.8 \mathrm{~km}^{2}$ (Zielinski et al. 2004). A parallel analysis was carried out using a lowered elevation limit of 1,524 meters to broaden the applicability of this study and to allow for more conservative approaches to habitat designation in the future. 


\section{Results}

Survey data

The surveys yielded 211 absence observations and 38 presence observations from the total of 249 sites. Of all absence points, 66 had either overlapping buffers with another absence point or were in very close proximity to a presence point. In order to reduce the probability of modeling absence points that were likely within the home ranges of surveyed bobcat, as shown by a presence observation within two kilometers, any absence point within this distance of a presence point was deleted While non-detection of a nearby animal is inevitable with any survey, especially with elusive carnivores, this step was taken to lessen that influence. This left a total of 145 absence points for analysis (Figure 1). A variety of different mammals were photographed throughout the study. Appendix A contains a sampling of the bobcat detections and photographs of various other mammals detected in the study.

The data used for the classification model consisted of a binary (absence/presence) response variable and six continuous predictor variables: canopy cover, canopy cover of conifers, stand age, basal area of conifers $>2.5 \mathrm{~cm} d b h$ (BAC), quadratic mean diameter (QMDA), and elevation (DEM). Out of 183 observations, $79.2 \%(n=145)$ were absence points, and $20.8 \%(n=38)$ were presence points. The average of the means inside the absence buffers was $67.4 \%$ for canopy cover, $67.1 \%$ for conifer cover, $38.5 \mathrm{~m}^{2} /$ ha for BAC, $29.2 \mathrm{~cm}$ for QMDA, and 
1437.1 $\mathrm{m}$ for DEM. The average of all the means for presence buffers was $76.1 \%$ for canopy cover, $75.5 \%$ for conifer cover, $49.4 \mathrm{~m}^{2} /$ ha for BAC, $42.6 \mathrm{~cm}$ for QMDA, and $1021.6 \mathrm{~m}$ for elevation. The degree of variance was also calculated to determine the level of heterogeneity inside each presence buffer (Table 1). All variables had a coefficient of variation below 0.5 .

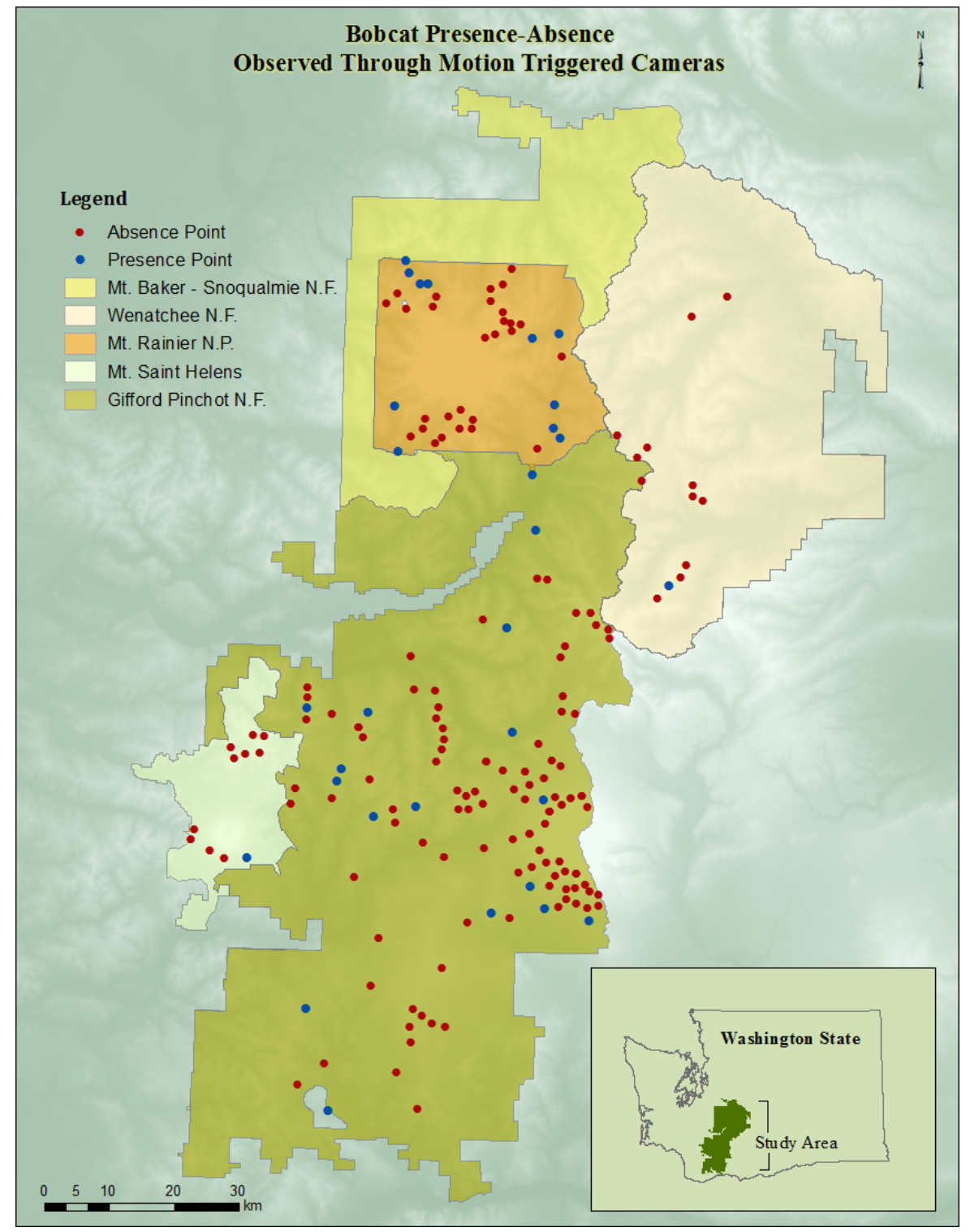

Figure 1. Presence and absence points and the study area of the Gifford Pinchot National Forest (including Mount St. Helens National Volcanic Monument), Mount Rainier National Park, and the southern part of Mount Baker-Snoqualmie and Wenatchee National Forest. 
Table 1: Means and coefficients of variation within the presence buffers to ensure that variance within each buffer was not significantly high.

\begin{tabular}{|l|l|l|l|l|l|}
\hline $\begin{array}{l}\text { Values within } \\
\text { buffers }\end{array}$ & QMDA & $\begin{array}{l}\text { Canopy } \\
\text { Cover }\end{array}$ & $\begin{array}{l}\text { Canopy } \\
\text { Cover of } \\
\text { Conifers }\end{array}$ & BAC & DEM \\
\hline Mean & $42.64 \mathrm{~cm}$ & $76.10 \%$ & $75.54 \%$ & $49.41 \mathrm{~m}^{2} / \mathrm{ha}$ & $1021.62 \mathrm{~m}$ \\
\hline $\begin{array}{l}\text { Coefficient of } \\
\text { variation }\end{array}$ & 0.46 & 0.27 & 0.28 & 0.49 & 0.01 \\
\hline
\end{tabular}

\section{Classification tree}

The twenty cross validation iterations carried out in $\mathrm{R}$ by sub-setting the observations revealed an average correct classification of $88 \%$; the spread of correct classifications was between $85 \%$ and $91 \%$ for all iterations (Table 2 and 3). This shows that the model was not significantly altered by the addition or subtraction of certain points or groups of points and accurately classified most of the observations into presence and absence.

The final tree, using $100 \%$ of the data, had only three nodes (Figure 2). Thus, integration into ArcGIS for variable reclassification and analysis was plausible without pruning, which is a step often required to bring classification trees down to a useful size (Baker et al. 2006). The classification tree's first split, and therefore its most important, was at 1,303 meters DEM. Above this height was the main prediction of bobcat absence, and below, the data was subsequently divided by QMDA at $43.45 \mathrm{~cm}$ and again by elevation at 1,070 $\mathrm{m}$. To understand how well the individual branches were accurately classifying the data, the number of correctly classified observations in each branch was divided by the total number of 
observations in that branch. The first break to the left, $>1,303 \mathrm{~m}$, has a correct classification percentage of $95 \%$ (103 of the 108 buffers are correctly classified as an absence). The second branch, $<1,303 \mathrm{~m}$ and $<43.45 \mathrm{~cm}$, classified $73 \%$ correctly as absences ( 36 out of 49 ). The third branch, $<43.45 \mathrm{~cm}$ and between 1,070 to 1,303 $\mathrm{m}$, classified $57 \%$ correctly as presence observations ( 4 out of 7 ). The fourth branch, $>43.45 \mathrm{~cm}$ and $<1,070 \mathrm{~m}$, correctly classified $89 \%$ of the observations as presence (17 out of 19).

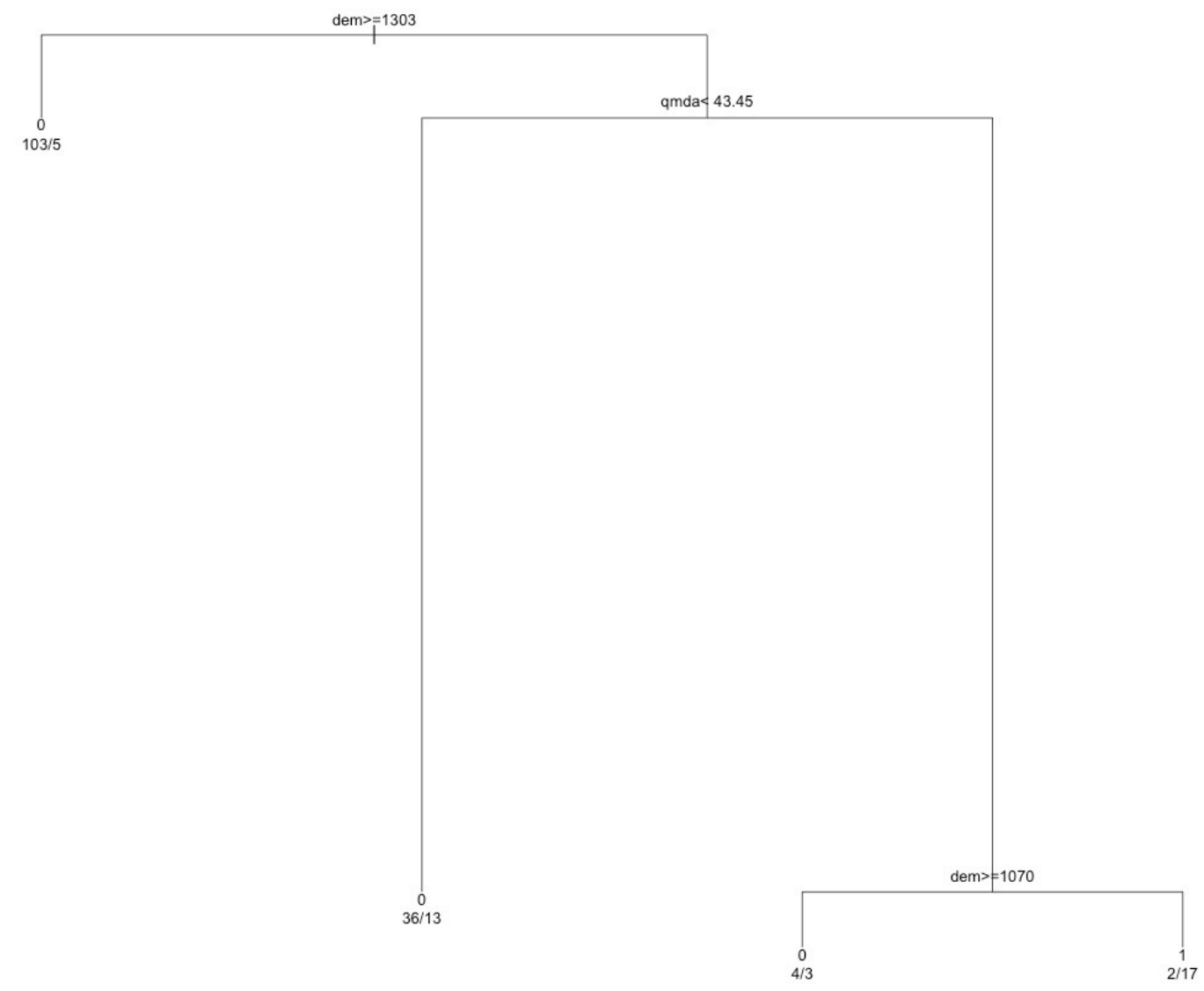

Figure 2. Classification tree created through modeling the correlation of bobcat presence and absence with the predictor variables. Variables used in the creation of the tree are elevation (dem) and tree diameter (qmda). 
Table 2: Cross-validation of the survey data using $80 \%$ subset to run the model and $20 \%$ to validate.

\begin{tabular}{|c|c|c|c|c|c|c|c|}
\hline Subset & Run & Correct & Incorrect & \multicolumn{3}{|c|}{$\mathrm{P}=$ predicted, $\mathrm{O}=$ observed } & Variables used \\
\hline \multirow{3}{*}{$\begin{array}{l}80 \% / \\
20 \%\end{array}$} & \multirow[t]{3}{*}{1} & \multirow[t]{3}{*}{$91 \%$} & \multirow[t]{3}{*}{$9 \%$} & & $0-0$ & $0-1$ & \multirow{3}{*}{$\begin{array}{l}\text { DEM (elev.) } \\
\text { QMDA (tree } \\
\text { diam.) }\end{array}$} \\
\hline & & & & $\mathrm{P}-0$ & 112 & 9 & \\
\hline & & & & P-1 & 5 & 23 & \\
\hline & \multirow[t]{3}{*}{2} & \multirow[t]{3}{*}{$87 \%$} & \multirow[t]{3}{*}{$13 \%$} & & $0-0$ & $0-1$ & \multirow[t]{3}{*}{ DEM, QMDA } \\
\hline & & & & P-0 & 114 & 18 & \\
\hline & & & & P-1 & 1 & 115 & \\
\hline & \multirow[t]{3}{*}{3} & \multirow[t]{3}{*}{$90 \%$} & \multirow[t]{3}{*}{$10 \%$} & & $0-0$ & $0-1$ & \multirow{3}{*}{$\begin{array}{l}\text { DEM, QMDA, } \\
\text { Conifer Cover }\end{array}$} \\
\hline & & & & $\mathrm{P}-0$ & 103 & 11 & \\
\hline & & & & P-1 & 3 & 17 & \\
\hline & \multirow[t]{3}{*}{4} & \multirow[t]{3}{*}{$89 \%$} & \multirow[t]{3}{*}{$11 \%$} & & $0-0$ & $0-1$ & \multirow[t]{3}{*}{ QMDA, DEM } \\
\hline & & & & P-0 & 118 & 15 & \\
\hline & & & & $\mathrm{P}-1$ & 2 & 13 & \\
\hline & \multirow[t]{3}{*}{5} & \multirow[t]{3}{*}{$87 \%$} & \multirow[t]{3}{*}{$13 \%$} & & $0-0$ & $0-1$ & \multirow[t]{3}{*}{ DEM, QMDA } \\
\hline & & & & $\mathrm{P}-0$ & 115 & 17 & \\
\hline & & & & $\mathrm{P}-1$ & 2 & 16 & \\
\hline & \multirow[t]{3}{*}{6} & \multirow[t]{3}{*}{$88 \%$} & \multirow[t]{3}{*}{$12 \%$} & & $0-0$ & $0-1$ & \multirow[t]{3}{*}{ DEM, QMDA } \\
\hline & & & & $\mathrm{P}-0$ & 113 & 9 & \\
\hline & & & & $\mathrm{P}-1$ & 9 & 19 & \\
\hline & \multirow[t]{3}{*}{7} & \multirow[t]{3}{*}{$87 \%$} & \multirow[t]{3}{*}{$13 \%$} & & $0-0$ & $0-1$ & \multirow[t]{3}{*}{ DEM, QMDA } \\
\hline & & & & P-0 & 112 & 15 & \\
\hline & & & & P-1 & 4 & 17 & \\
\hline & 8 & $88 \%$ & $12 \%$ & & $0-0$ & $0-1$ & DEM, QMDA \\
\hline & & & & $\mathrm{P}-0$ & 111 & 15 & \\
\hline & & & & P-1 & 2 & 17 & \\
\hline & 9 & $86 \%$ & $14 \%$ & & $0-0$ & $0-1$ & DEM, QMDA \\
\hline & & & & P-0 & 116 & 19 & \\
\hline & & & & $\mathrm{P}-1$ & 2 & 14 & \\
\hline & 10 & $85 \%$ & $15 \%$ & & $0-0$ & $0-1$ & DEM \\
\hline & & & & P-0 & 111 & 19 & \\
\hline & & & & $\mathrm{P}-1$ & 2 & 11 & \\
\hline
\end{tabular}


Table 3: Cross-validation of the survey data using $85 \%$ subset to run the model and $15 \%$ to validate.

\begin{tabular}{|c|c|c|c|c|c|c|c|}
\hline Subset & Run & Correct & Incorrect & \multicolumn{3}{|c|}{$\mathrm{P}=$ predicted $\mathrm{O}=$ observed } & Variables used \\
\hline \multirow{30}{*}{$\begin{array}{l}85 \% / \\
15 \%\end{array}$} & \multirow[t]{3}{*}{1} & \multirow[t]{3}{*}{$88 \%$} & \multirow[t]{3}{*}{$12 \%$} & & $0-0$ & $0-1$ & \multirow{3}{*}{$\begin{array}{l}\text { DEM (elev.), } \\
\text { QMDA (tree } \\
\text { diam.) }\end{array}$} \\
\hline & & & & $\mathrm{P}-0$ & 122 & 14 & \\
\hline & & & & $\mathrm{P}-1$ & 5 & 19 & \\
\hline & \multirow[t]{3}{*}{2} & \multirow[t]{3}{*}{$90 \%$} & \multirow[t]{3}{*}{$10 \%$} & & $0-0$ & $0-1$ & \multirow{3}{*}{$\begin{array}{l}\text { DEM, QMDA, } \\
\text { Basal Area of } \\
\text { Conifers }\end{array}$} \\
\hline & & & & $\mathrm{P}-0$ & 113 & 11 & \\
\hline & & & & $\mathrm{P}-1$ & 4 & 23 & \\
\hline & \multirow[t]{3}{*}{3} & \multirow[t]{3}{*}{$89 \%$} & \multirow[t]{3}{*}{$11 \%$} & & $0-0$ & $0-1$ & \multirow[t]{3}{*}{ DEM, QMDA } \\
\hline & & & & $\mathrm{P}-0$ & 122 & 15 & \\
\hline & & & & $\mathrm{P}-1$ & 2 & 16 & \\
\hline & \multirow[t]{3}{*}{4} & \multirow[t]{3}{*}{$88 \%$} & \multirow[t]{3}{*}{$12 \%$} & & $0-0$ & $0-1$ & \multirow[t]{3}{*}{ DEM, QMDA } \\
\hline & & & & $\mathrm{P}-0$ & 130 & 19 & \\
\hline & & & & $\mathrm{P}-1$ & 1 & 14 & \\
\hline & \multirow[t]{3}{*}{5} & \multirow[t]{3}{*}{$87 \%$} & \multirow[t]{3}{*}{$13 \%$} & & $0-0$ & $0-1$ & \multirow[t]{3}{*}{ DEM, QMDA } \\
\hline & & & & $\mathrm{P}-0$ & 119 & 19 & \\
\hline & & & & P-1 & 2 & 16 & \\
\hline & \multirow[t]{3}{*}{6} & \multirow[t]{3}{*}{$88 \%$} & \multirow[t]{3}{*}{$12 \%$} & & $0-0$ & $0-1$ & \multirow{3}{*}{$\begin{array}{l}\text { DEM, QMDA, } \\
\text { Conifer Cover }\end{array}$} \\
\hline & & & & $\mathrm{P}-0$ & 123 & 13 & \\
\hline & & & & P-1 & 6 & 19 & \\
\hline & \multirow[t]{3}{*}{7} & \multirow[t]{3}{*}{$89 \%$} & \multirow[t]{3}{*}{$11 \%$} & & $0-0$ & $0-1$ & \multirow{3}{*}{$\begin{array}{l}\text { DEM, QMDA, } \\
\text { Conifer Cover }\end{array}$} \\
\hline & & & & $\mathrm{P}-0$ & 120 & 12 & \\
\hline & & & & $\mathrm{P}-1$ & 6 & 23 & \\
\hline & 8 & $86 \%$ & $14 \%$ & & $0-0$ & $0-1$ & DEM, QMDA \\
\hline & & & & $\mathrm{P}-0$ & 111 & 19 & \\
\hline & & & & $\mathrm{P}-1$ & 1 & 15 & \\
\hline & 9 & $89 \%$ & $11 \%$ & & $0-0$ & $0-1$ & DEM, QMDA \\
\hline & & & & $\mathrm{P}-0$ & 121 & 14 & \\
\hline & & & & P-1 & 4 & 19 & \\
\hline & 10 & $87 \%$ & $13 \%$ & & $0-0$ & $0-1$ & DEM, QMDA, \\
\hline & & & & $\mathrm{P}-0$ & 114 & 17 & Conifer Cover \\
\hline & & & & $\mathrm{P}-1$ & 2 & 14 & \\
\hline
\end{tabular}


Integration into GIS

The branches of the classification tree that predicted presence or absence were used in the reclassification of raster layers in ArcGIS (Figure 3). The step of reclassifying raster variables combined the results of the bobcat model with habitat information from past fisher habitat research on suggested parameters of elevation and tree diameter. The first branch in the model, which highlights a 95\% probability of bobcat absence at elevations above $1,303 \mathrm{~m}$, suggests potentially suitable habitat for fisher as bobcats are likely absent above this elevation. Another elevation division was used in the reclassification process to account for the third branch of the model that predicts a $89 \%$ probability of presence below 1,070 m, however, it should be noted that since classification trees are read stepwise, this particular elevation factor only comes into play if the cell also has a QMDA value $>43.45 \mathrm{~cm}$. The left side of this third node, with a correct classification of only $57 \%$ in the absence category did not have strong predictive power, but due to the potential importance of wide trees for fishers, this range of values (QMDA > 43.45 and DEM between 1,070-1,303) could potentially carry increased habitat value. Figure 4 shows the spatial representation of bobcat absence probabilities as determined by the classification tree. 


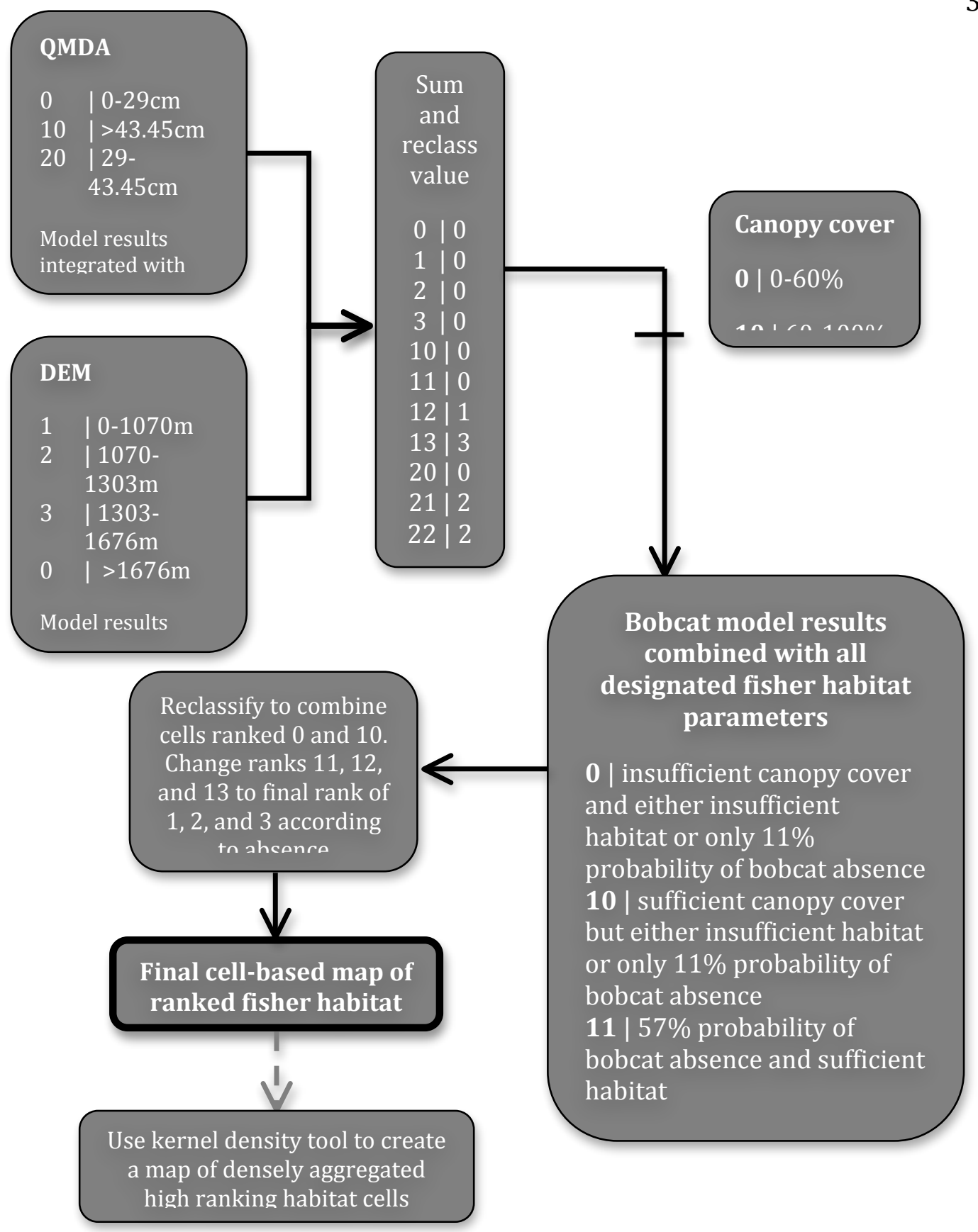

Figure 3. Schematic diagram showing: 1) the reclassification and summing of cells of the variables designated by the model 2) integrating of the canopy cover layer 3) summing and reclassification to create the final fisher habitat map and 4) the creation of the density map. 


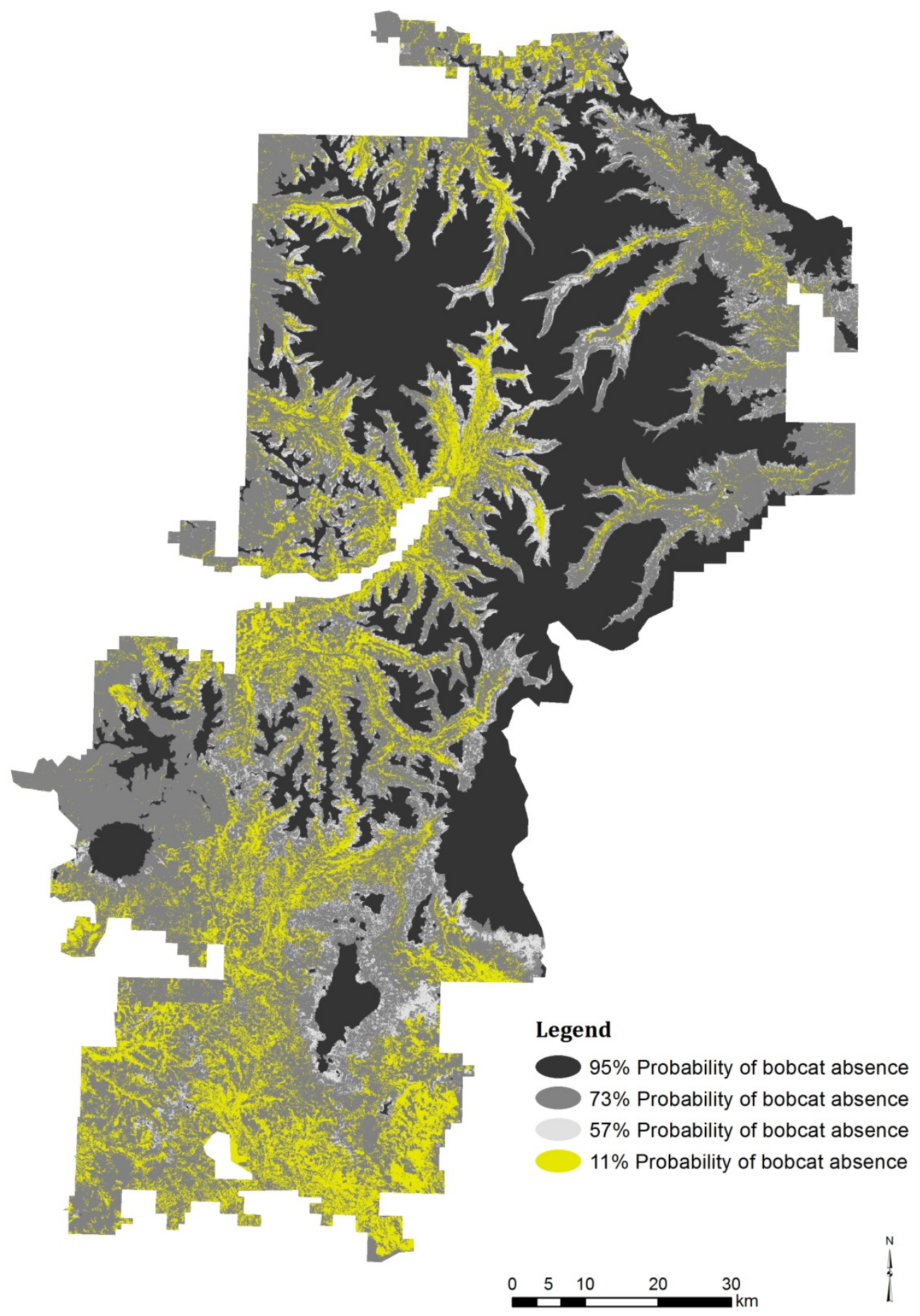

Figure 4. Map of bobcat absence probabilities as determined by the classification tree model. 
Fisher habitat requirements of elevation and tree diameter were incorporated during the initial reclassification step to designate cells that were too high in elevation or too low in tree diameter as unsuitable. Figure 5 is a representation showing high ranking fisher habitat using parameters of elevation, tree diameter, and canopy cover before the integration of the bobcat model results. Since trees below $29 \mathrm{~cm}$ are not normally used by fishers for natal dens and are less associated with fisher presence, any cells with a QMDA value below this, were given a rank of 0 (unsuitable habitat cell). Cells in the range of $29 \mathrm{~cm}$ to $43.45 \mathrm{~cm}$ were designated with a 20, which was the highest rank for the QMDA layer, because above the QMDA value of $43.45 \mathrm{~cm}$, cells can be highly correlated with bobcat presence and cells below $29 \mathrm{~cm}$ are designated as unsuitable for fisher habitat (Figure 3). Without the bobcat model, stands with trees above $43.45 \mathrm{~cm}$ would also receive a rank of 20 , but considering its strong correlation with bobcat presence, areas with a QMDA above $43.45 \mathrm{~cm}$ were given a rank of only 10; these cells would be designated as potential habitat only if the elevation of that cell was also $>1,303$ $\mathrm{m}$. Elevation was the strongest predictor of bobcat absence, and overall, was divided by three break points in the creation of the initial reclassified elevation layer. An upper limit of 1,676 m was also integrated with the model results in the reclassification of this layer. Cells with an elevation above 1,676 were given a rank of 0 . Cells with an elevation from 1,303 to 1,676 m (95\% probability of absence) were given a rank of 3 , the highest rank in the elevation layer. Cells with an elevation from 1,070 to 1,303 were given a rank of 2 (the final rank of suitability 
would be determined by the tree diameter in this cell suggesting that the likelihood of bobcat absence is either $57 \%$ or $73 \%$ ), and lastly, those cells with an elevation under 1,070 were given a rank of 1 (meaning low suitability and a $89 \%$ likelihood of presence if the tree diameter was also above $43.45 \mathrm{~cm}$ ).

The basal area of silver fir, at 1,676 meters was calculated and found to be an average of $30.64 \mathrm{~m}^{2} /$ ha (standard deviation of $20.65 \mathrm{~m}^{2} / \mathrm{ha}$ ). This highlighted that silver fir was still in dense communities at this elevation. Silver fir maintained a relatively high basal area count past 2000 meters, but to be conservative and to plan for the potential of uncommonly deep snow in certain years, the upper limit for the primary map of fisher habitat was kept at 1,676 meters. The secondary map of suitable habitat using the upper limit of 1,524 meters was created through the same process with only the upper elevation value altered.

The accuracy of the LEMMA layers used in the creation of the habitat suitability was validated by examining the correlation coefficient value, which LEMMA determined by comparing their predicted forest values to observed values through on-the-ground observations. The correlation coefficient and root mean squared error (normalized measure) for canopy cover was 0.75 and 0.20 , and these measures for QMDA were 0.72 and 0.43 (Ohmann and Gregory 2002). These values signified that the forest data layers were predicting values with a high degree of accuracy. 


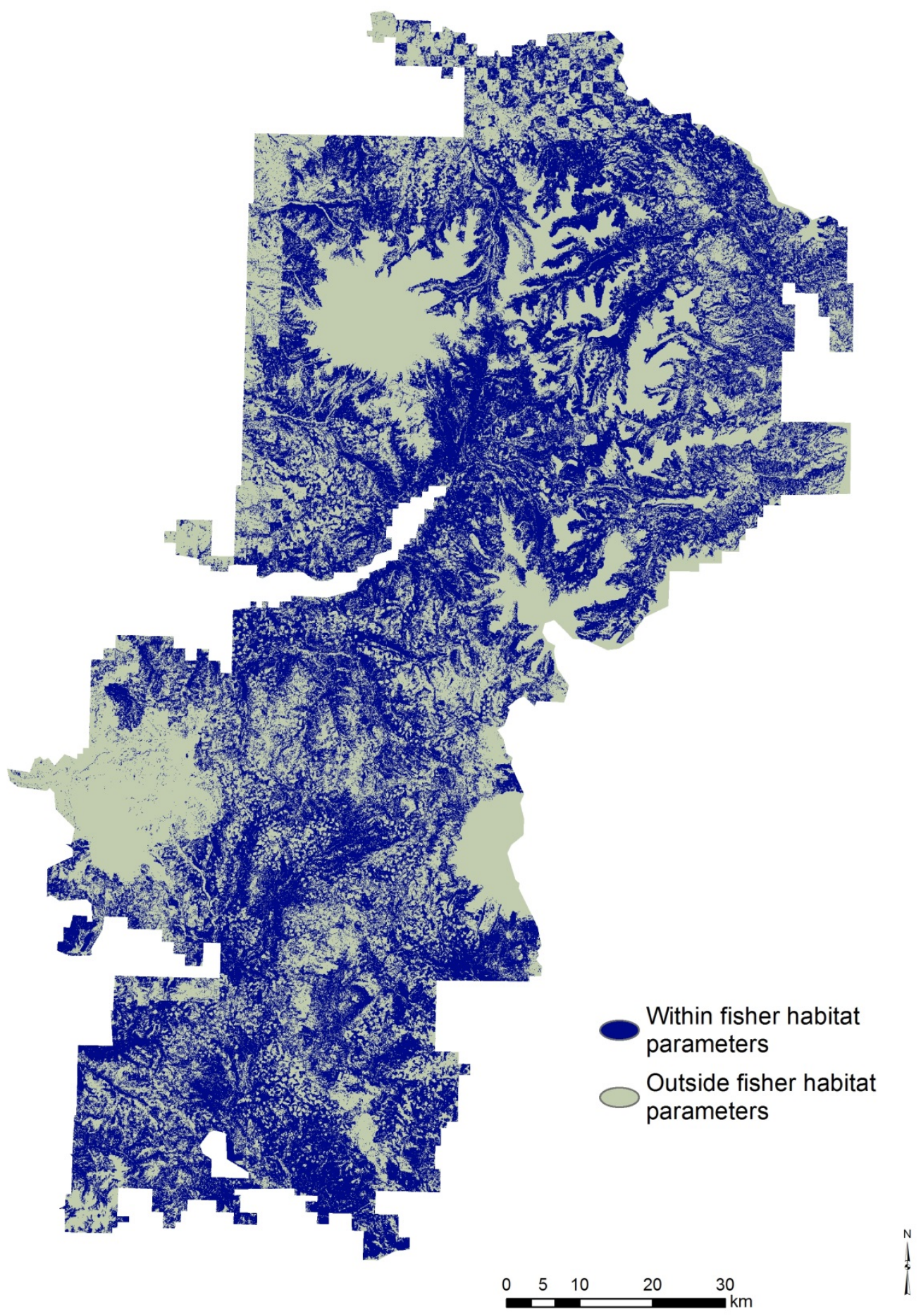

Figure 5. Cells within and outside of fisher habitat parameters of canopy cover, elevation, and tree diameter before the integration of the bobcat distribution model results. 
The summing of the elevation layer $(0,1,2,3)$ and the tree diameter layer $(0$, $10,20)$ created a variation of ranks from 0 to $23(0,1,2,3,10,11,12,13,20,21,22$, 23). This resulting layer, with the model result thresholds and the fisher habitat parameter thresholds, was overlaid and summed with the layer of canopy cover (ranked 0 and 10 ) to locate suitable areas where the sum was either 11,12 , or 13 , meaning that there was a greater than $57 \%$ probability of bobcat absence and a sufficient level of available habitat components. This layer was further reclassified to combine all cells ranked 0 and 10 to a combined rank of 0 to now have one rank that represents any unsuitable cell regardless of the source of its unsuitability. The ranks of 11,12 , and 13 were simply converted to 1,2 , and 3 to make further steps and reclassifications clear and standardized. These steps created the primary habitat map showing a cell-based representation of different levels of bobcat absence in areas of high $(1,2$, and 3 ) or low (0) ranking fisher habitat (figure 6). This primary map of potential fisher habitat was incorporated into the kernel density tool to allow another manner of interpretation and integration into the determination of release sites by highlighting areas of densely aggregated habitat cells (Figure 7). The kernel density function was set to give a higher weight to cells with a higher rank ( 3 more than 2, 2 more than 1) so that a density surface could be created that translates the different levels of bobcat absence probability. The kernel density tool was set to apply a search distance of 3,534 meters, which represents the diameter of an average female fisher's home range of $9.8 \mathrm{~km}^{2}$ (Zielinski et al. 2004). As this function is determining density around a particular cell, it gives greater 
weight to cells closest to the particular cell and this weight diminishes until it reaches the search distance of 3,534 meters. The home range of a female fisher was chosen as a conservative measure planning towards the lower end of the fisher home range spectrum. A last habitat rendering was created using the same process as the primary habitat analysis but with an elevation limit of 1,524 meters rather than 1,676 meters (Figures 8 and 9). This representation was not used in the overall habitat interpretation, but may prove to be useful in building a broader focus of fisher habitat and bobcat distribution in the study area.

The most aggregated area of possible reintroduction for fisher can be seen in the William O. Douglas Wilderness at the border of the Gifford Pinchot National Forest (GPNF) and Wenatchee National Forest (WNF), in the Norse Peak Wilderness northeast of Mount Rainier in the WNF, and in Indian Heaven Wilderness in the southern portion of the GPNF (Figure 10). These areas had the greatest concentration of high ranking habitat and with the exception of the location in the Indian Heaven Wilderness, they all had a surrounding surface of relatively dense fisher habitat. 


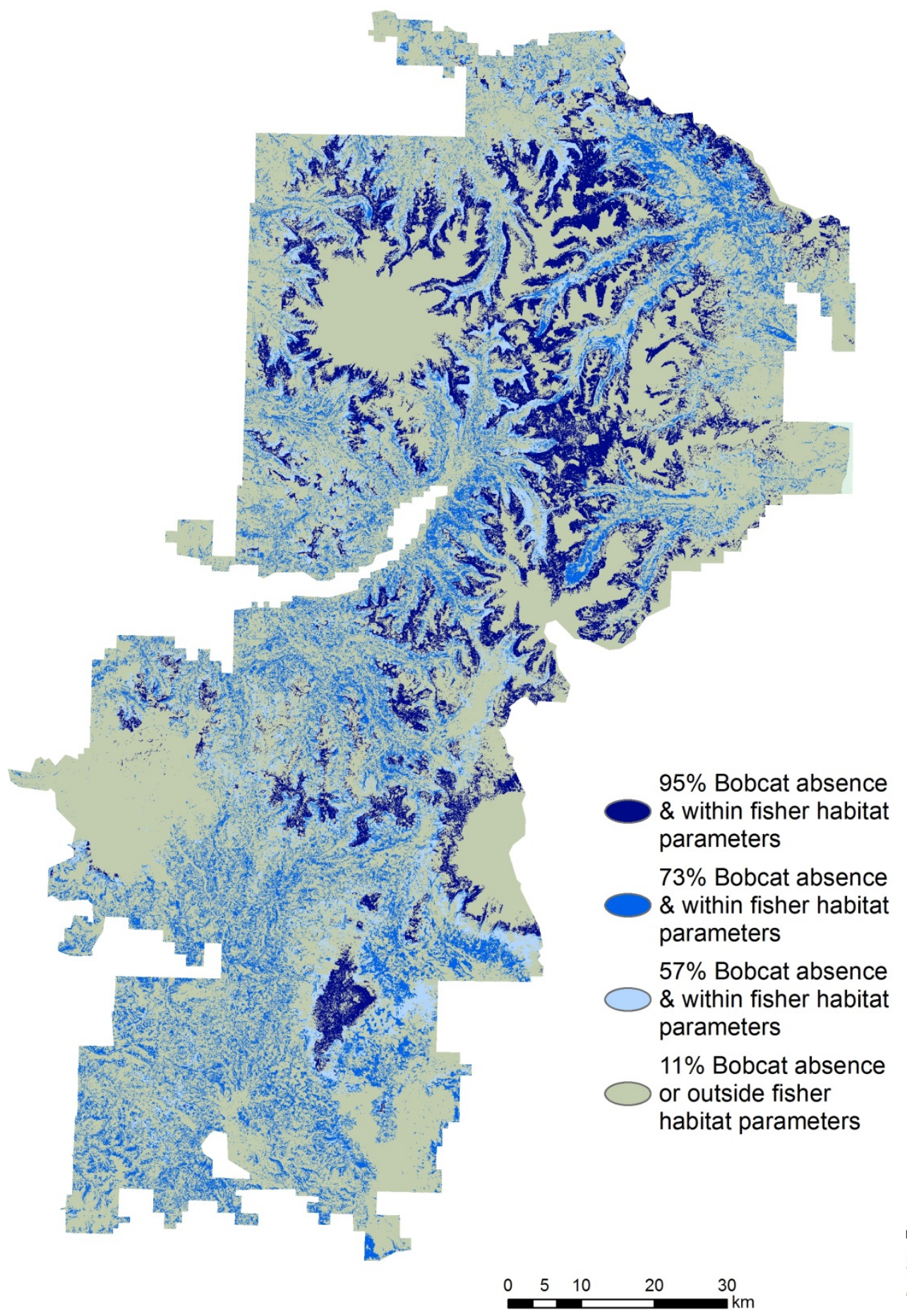

Figure 6. Cell-based representation of fisher habitat suitability as determined by fisher habitat parameters and the varying levels of bobcat absence probability designated by the model. 


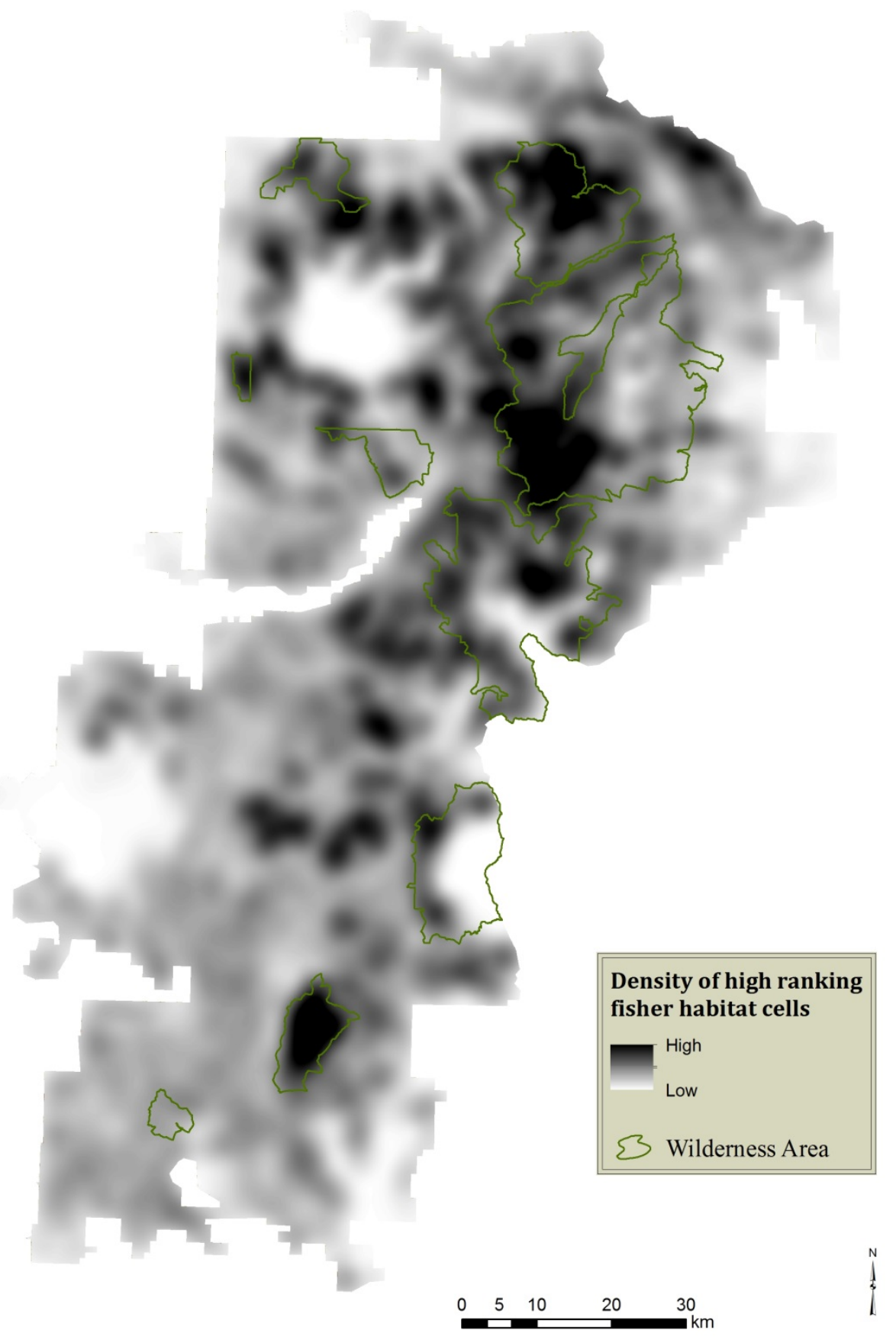

Figure 7. Map showing the density of fisher habitat cells with greater weight being given to cells with a higher likelihood of bobcat absence. Cells ranked 3 (95\% probability of absence) are weighted most heavily, cells ranked 2 (73\% probability of absence) carry the middle weight, and cells ranked 1 (57\% probability of absence) are given the least weight. All cells measured in these ranks have sufficient fisher habitat parameters of canopy cover, elevation, and tree diameter. 


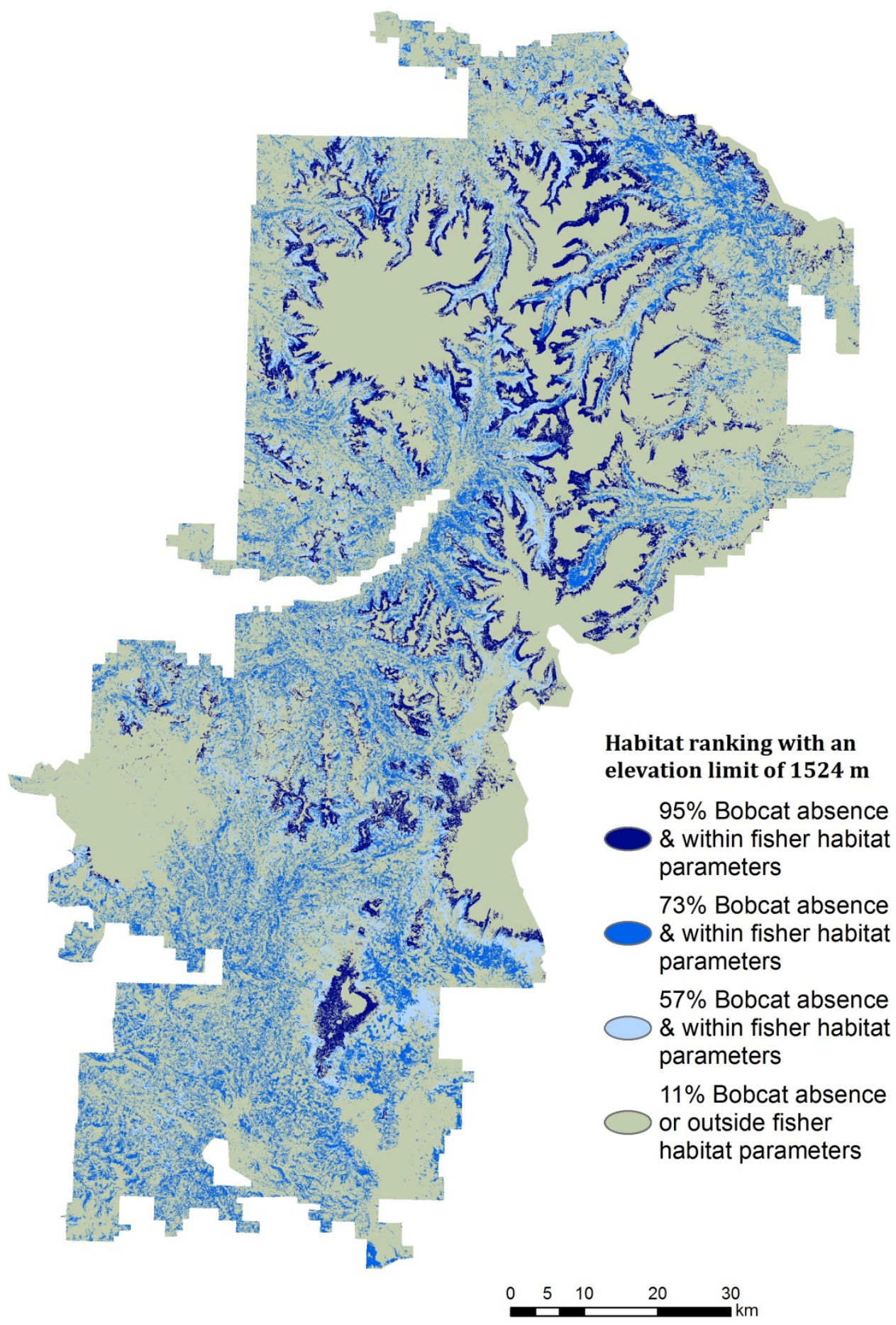

Figure 8. Figure 6. Cell-based representation of fisher habitat suitability as determined by fisher habitat parameters and the varying levels of bobcat absence probability designated by the model using an upper elevation limit of 1,524 meters (5,000 feet). 


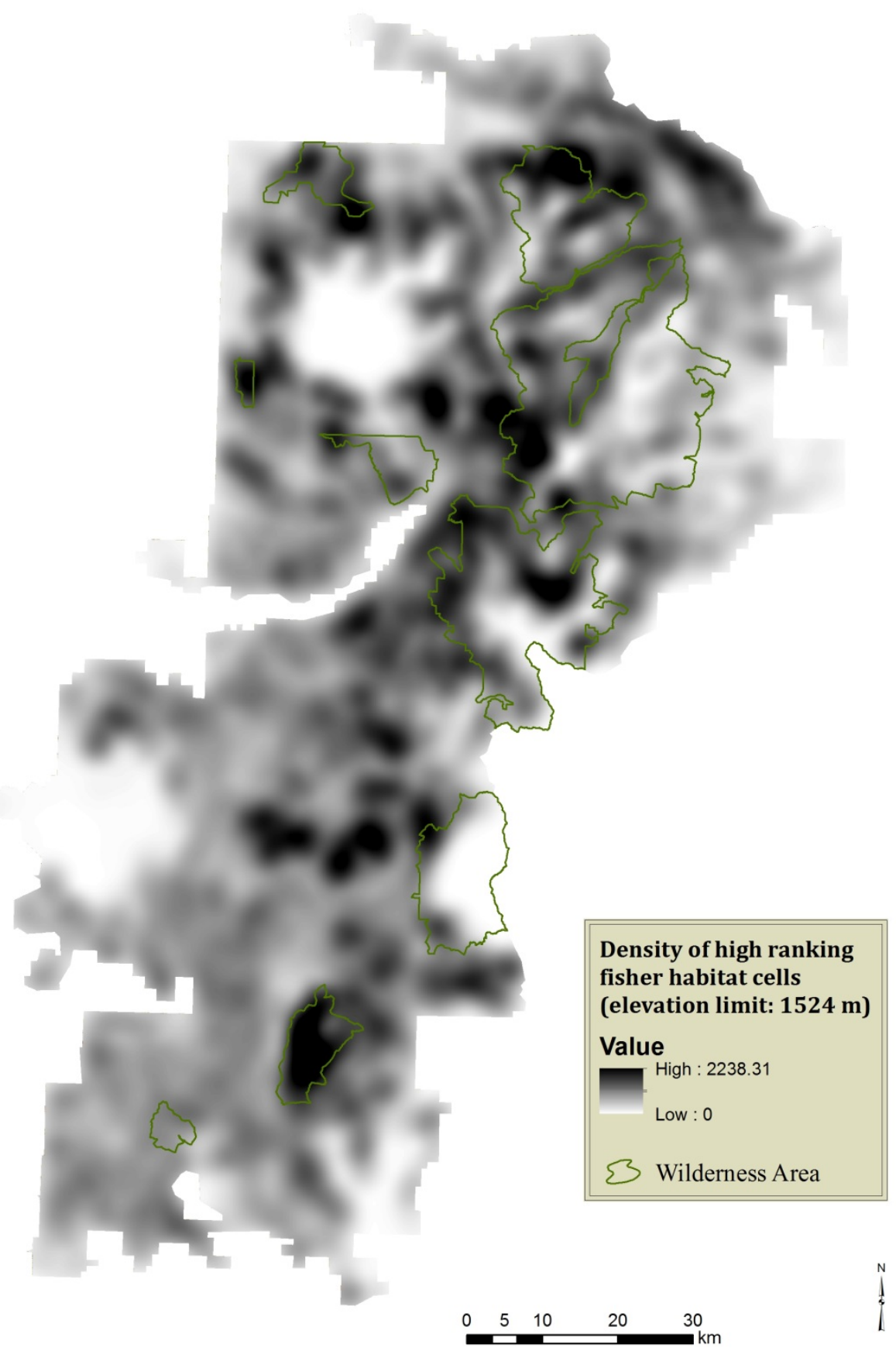

Figure 9. Density of fisher habitat cells with greater weight being given to cells with a higher likelihood of bobcat absence and an upper elevation limit of 1,524 meters (5,000 feet). Cells ranked 3 (95\% probability of absence) are weighted most heavily, cells ranked 2 (73\% probability of absence) carry the middle weight, and cells ranked 1 (57\% probability of absence) are given the least weight. All cells measured in these ranks have sufficient fisher habitat parameters of canopy cover, elevation, and tree diameter. 


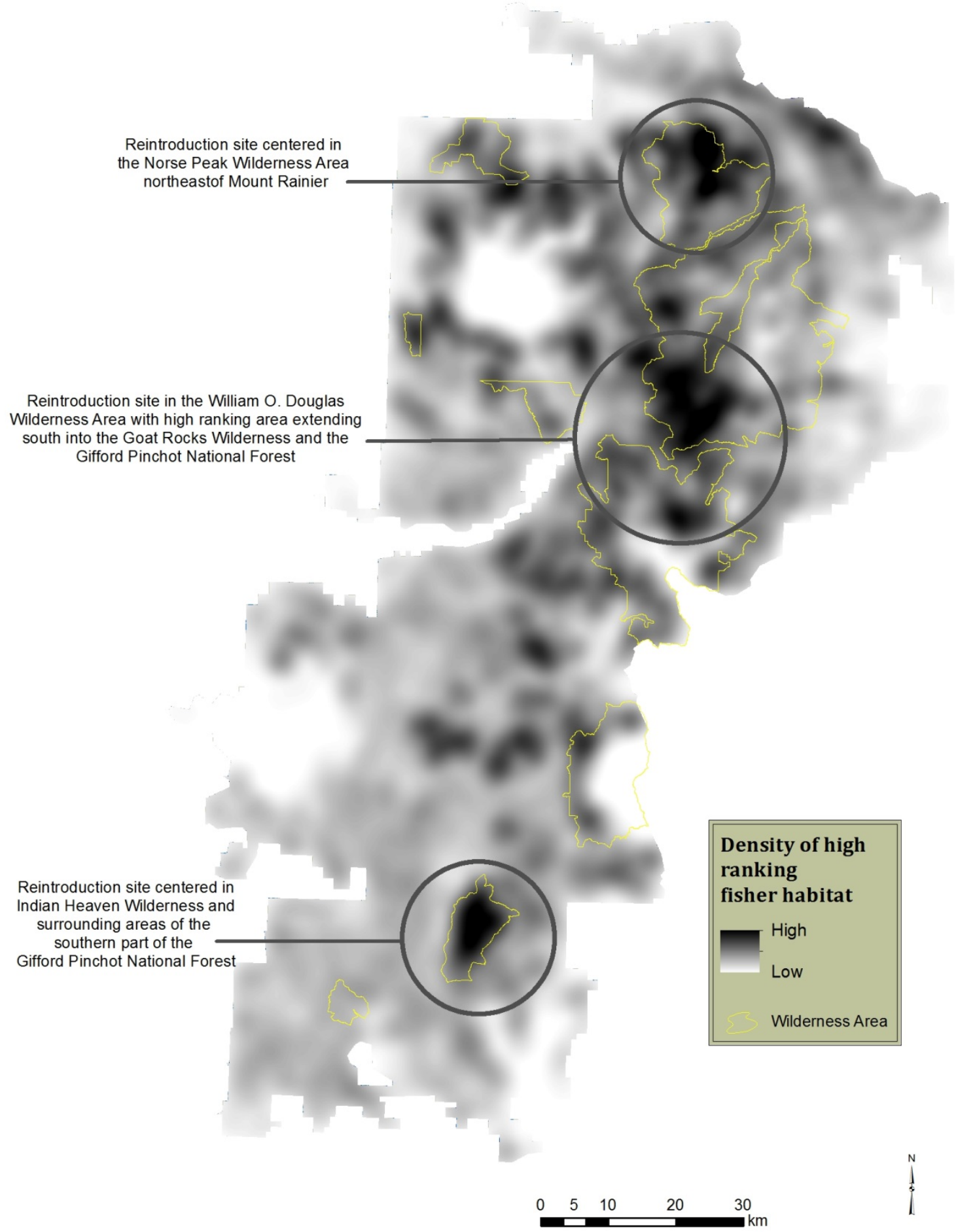

Figure 10. The three densest areas of high ranking fisher habitat, signifying potential areas for reintroduction release locations. 


\section{Discussion}

The results of the research highlighted elevation and tree diameter as variables indicative of bobcat presence and absence, and the habitat analysis presented areas where fishers may be able to establish a self-sustaining population because of the existence of sufficient habitat components and a high likelihood of bobcat absence. The area with the highest density of fisher habitat is in the William 0. Douglas Wilderness. This federally designated wilderness area straddles the boundary between the Gifford Pinchot National Forest (GPNF) and the Wenatchee National Forest (WNF) and encompasses 166,000 acres of federally protected land. Large rock summits, lakes, and ponds are common on the landscape and old-growth forest stands populate the lower elevation areas. To the south of the William 0. Douglas and in close enough proximity to allow for dispersal is the Goat Rocks Wilderness area, which encompasses 105,600 acres of protected land. Goat Rocks is home to a diverse array of wildlife species including its namesake, the mountain goat. The most northerly location with a high density of top ranking habitat is in the Norse Peak Wilderness northeast of Mount Rainier; being closely linked to the larger area of dense fisher habitat located in the William 0. Douglas, it serves as a potentially important location for connectivity and the establishment of a large range of contiguous fisher habitat. Most of the 52,180 acres of the Norse Peak Wilderness is located in the WNF, but 15,654 acres lie within the Mount BakerSnoqualmie National Forest. Indian Heaven Wilderness was also found to be a high 
ranking area for reintroduction. Located in the southern part of the GPNF, this 20,600 acre wilderness areas is a mid to upper elevation wilderness known for its subalpine meadows, abundant lakes, and stretches of old-growth forest. Being wilderness areas, William O. Douglas, Goat Rocks, Norse Peak, and Indian Heaven are assured heightened protection and restricted access, thereby increasing the quality of these areas as remote and wild forests within which fishers can establish home ranges. As seen in the Olympics and other study areas, fishers do succumb to collisions with cars; given the near absence of roads in these wilderness areas, this type of mortality would most likely be very low. The ultimate determination of release locations will be in the hands of the Washington Department of Fish and Wildlife and the collaborating organizations involved in the reintroduction effort.

The southern Washington Cascades contain several areas with a relatively high density of suitable habitat and due to the geographic location of this study area, it carries the added benefit of connectivity. Increased dispersal opportunities supply a valuable quality that can help ensure the continuation of the species many years after the reintroduction. Being connected to North Cascades allows the possibility for future expansion of fisher populations to the north, which is especially important considering biotic alterations that may increase due to climate change. Reintroduction sites near the crest of the Cascades support the possibility of eastern expansion into areas where high elevation habitat is plausible because of rain shadow effects (Aubry and Houston 1992). 
Surveys

The model yielded a greater proportion of false negatives (15\%) than false positives (11\%). Although the disparity is minimal, I assume the difference is due to the fact that bobcats, like many different carnivore species, are oftentimes difficult to detect, even when they are in the vicinity. The detectability of carnivores is a factor influencing any research that depends on the observations of these animals as they are usually elusive and occurring in low densities (MacKenzie et al. 2002; Long et al. 2010). The survey technique employed by myself and researchers conducting the other surveys is intended to lessen this possibility by ensuring a long enough survey duration and by incorporating an attractant designed to bring animals to the camera set. The 28-day survey duration was established as a standard duration in surveys of fishers, American marten, lynx, and wolverine (Zielinski and Kucera 1995). This duration was established through research on patterns of latency-tofirst-detection (LTD) for these various carnivores. The bobcat's roaming habits and home range size are similar to that of the fisher, lynx, and wolverine, and therefore the survey duration set up for these animals should represent an appropriate guideline for bobcat surveys. A carnivore survey study from the Green Mountain National Forest in Vermont found an average LTD for bobcats to be 9.8 days (Moruzzi et al. 2002). Larrucea (2007) in her study testing the ability to census bobcats with remote cameras, found that adding an additional four weeks of survey duration to a 28-day survey, did not increase the likelihood of detection. Considering that the average LTD for my surveys was 12.9 days, the 28-day survey 
duration is suitable for the analysis. If future steps were to be taken towards enhancing this research, an occupancy study would help to clear up the unanswered question of detectability. An occupancy model can be logistically intensive yet is one of the few ways to examine detectability for carnivores (MacKenzie et al. 2002).

\section{The Model}

Considering the results of the cross validation and calculations of predictive power, it is clear that the model is robust and classifying with a high degree of accuracy. The strength of elevation in predicting bobcat absence is likely due to the influence of deeper snow and the scarcity of trees in higher elevation zones. The deeper snow pack makes hunting more difficult for bobcats and is the primary factor limiting their northerly boundary where their range meets that of the Canada lynx. Also, the lower abundance of trees in high elevations has a strong effect on prey densities and, therefore, the overall fitness of bobcats. In addition to these factors, there would be a scarcity of fallen branches, root wads, and other treesourced habitat components needed by females for the raising of kittens. While these limitations may affect fishers in this elevation gradient, research suggests that fishers may be able to utilize higher zones than bobcats who rely on stealth and feline hunting strategies of traversing their home range in a zig-zag pattern and whose diets are often less varied than that of the fisher (Weir, Harestad, and Wright 2005; Hanson 2007). There were a few presence observations above the delineated 
split of 1,303 $\mathrm{m}$. This likely represents the upper reaches of a male bobcat's home range, one whose core range is located at a lower elevation, or from a transient male, one to two years old, who is looking to establish a home range. Transient males sometimes travel long distances in search of suitable territory and in areas outside the normal range of most bobcats (Neale and Sacks 2001; Benson, Chamberlain, and Leopold 2004). Tree diameter, as a determinant of presence and absence, is likely a reflection of stand diversity, age, the presence of suitable prey, and the existence of fine-scale habitat components such as large fallen trees.

GIS

The process of creating the ranks of bobcat probability and fisher habitat suitability required a balancing of known fisher habitat requirements with the occasionally contradictory results of the model. Much of the relatively good habitat according to bobcat absence is in moderate to high elevation areas, areas verging on risky habitat for fishers due to deep snow packs. Unusually deep snow pack in certain years could render these areas less suitable; however, this would probably be a rare occurrence. The areas with the highest probability of bobcat presence are, in certain places, the same areas likely to support a healthy population of fishers, yet there is enough disparity that areas with both good fisher habitat components and a low likelihood of bobcat were able to be found. The model shows that bobcats are commonly found in areas with wide diameter trees, which is also a habitat 
requirement for fishers, yet, as had been found by Zielinski et al., fisher home ranges in the Sierra Nevada were actually located most commonly in areas with only moderately sized trees, 29-61 cm (Zielinski et al. 2004). The only areas with tree diameter averages $>43.45 \mathrm{~cm}$ that made it into the fisher habitat map were in areas $>1,303$ meters in elevation. The existence of a model artifact can be seen through the spatial representations in that areas with a $57 \%$ probability of absence (rank of 1) are oftentimes closer to areas with a $95 \%$ probability of absence (rank of 3 ) than are those with a $73 \%$ probability of absence (rank of 2). When looking at the model results, it is clear that this gradient is created because cells with a QMDA value $<43.45 \mathrm{~cm}$ that have a rank of 2, can be located in any elevation under 1,303 $\mathrm{m}$, whereas cells with a rank of 1 are only, as dictated by the model, found in areas between 1,070 and 1,303 $\mathrm{m}$. Another reason is that as we go lower in elevation, under 1,303 $\mathrm{m}$, the upper reaches of this next zone have likely received lower levels of management and logging than the lowest areas of elevation and consequently, have greater proportions of large trees and are therefore less correlated with bobcat absence. Bobcat distributions in the forest would more likely follow a stepwise gradient of existence, yet the model is not able to relay this due to how forest management affects tree diameters and how management is affected by elevation. 
Implications for Fisher Reintroduction

Despite the assumed lower predation risk documented by the model in this research, it is important to note that females are generally more vulnerable to bobcat predation (Callas and Figura 2008; Higley and Matthews 2006). Although reintroduction logistical details are not the focus of this research, it would seem prudent to introduce fishers at a ratio of 3 females to 1 male; this ratio has been found to be indicative of increased reintroduction success in past attempts (Lewis, Powell, and Zielinski 2012). As for potential reintroduction dynamics, variations in the ratio might be applied wherein higher ratios of females are reintroduced in areas where habitat components are thought to be very good yet bobcat pressure might be high. Not only can this increase success by varying the application of suitability approaches, it also creates a monitoring environment where success can be explored through a lens of divergent release locations. The multiple site framework also follows suit with past reintroductions in that several specific release locations within the focus area are often used as target release sites. 


\section{Conclusion}

My research helps uncover previously unexplored variations of habitat suitability in Washington. It also supplies forest managers with habitat information and possible distribution patterns of the bobcat. Questions remain as to how cougar and fisher interactions will play out on the landscape after a reintroduction and how the return of wolves to the Cascades will affect bobcat and fisher interactions. Will the males have inherited qualities that supply them with the skills needed to avoid cougar predation, or will the potentially low density of cougars, as is generally the case, mean that this pressure will have little effect on the fishers? Although coyotes, like wolves, are not a common predator for fishers, they could be a larger factor in this region due to their ubiquitous presence, although the potential increase in wolf numbers will likely be a check on coyote populations. These questions are avenues of exploration whose answers will become more clear as we continue to uncover some of the elusive capacities of the carnivores in the Pacific Northwest.

The past existence of a species in a particular region does not guarantee a successful reintroduction. An in-depth investigation, such as this study, is an integral step in analyzing whether an area is able to sustain a reintroduced population of a native species and exactly where the reintroduction is most likely to be successful (Ewen et al. 2012). The connectivity and habitat values in the southern Washington Cascades are high, and an increased understanding of how and where bobcat predation may influence survivorship of released fishers 
advances our understanding of the dynamics of an important predator-prey relationship and the small-scale variations of fisher habitat suitability of the region. The work builds off research conducted by the Washington Department of Fish and Wildlife in their feasibility assessment for the reintroduction of fishers to Washington in which the southern Washington Cascades was highlighted as a potential site for the reintroduction of fishers. Working under this assumption, my research was focused on locating areas within the region that have the highest density of high ranking suitable habitat and that carry with them a high likelihood of bobcat absence. The pressure of bobcat predation will always be present, but with the incorporation of the distribution model results, this pressure can be reduced. My work has underlined areas with densely aggregated high ranking fisher habitat in several locations throughout the study area. The success of a reintroduction will depend on the collaboration of various stakeholders and the combining of research and practical application. Through integrated planning for a successful reintroduction, the fisher's current absence in the Washington Cascades can be reversed and we can see the return of this species to the native fabric of the region. 


\section{Bibliography}

Allen, A. W. 1983. Habitat Suitability Index Models: Fisher. Fort Collins, CO: Fish and Wildlife Service; FWS/OBS-82/10.45.

Aubry, K. B., and D.B. Houston. 1992. Distribution and Status of the Fisher (Martes pennant) in Washington. Northwest Naturalist 73:69-79.

Aubry, K. B., and J. C. Lewis. 2003. Extirpation and reintroduction of fishers (Martes pennanti) in Oregon: implications for their conservation in the Pacific states. Biological Conservation 114 (1):79-90.

Aubry, K. B., and C. Raley. 2006. Ecological Characteristics of Fishers ( Martes pennanti ) in the Southern Oregon Cascade Range Update : July 2006. Olympia, WA: USDA Forest Service-Pacific Northwest Research Station.

Baker, C., R. Lawrence, C. Montagne, and D. Patten. 2006. Mapping Wetlands and Riparian Areas Using Landsat ETM + Imagery and Decision-Tree-Based Models. Ecological Conservation 26 (2):465-474. 
Benson, J. F., M. J. Chamberlain, and B. D. Leopold. 2004. Land tenure and occupation of vacant home ranges by bobcats (Lynx rufus). Journal of Mammalogy 85 (5):983988.

Blankenship, T. L., A. M. Haines, M. E. Tewes, and N. J. Silvy. 2006. Comparing survival and cause-specific mortality between resident and transient bobcats Lynx rufus. Wildlife Biology 12 (3):297-303.

Brockway, D., C. Topik, M. Hemstrom, and W. Emmington. 1983. Plant Association and Management Guide for the Pacific Silver Fir Zone: Gifford Pinchot National Forest. Trout Lake, WA: USDA Forest Service.

Buchanan, J. B., R. W. Lundquist, and K. B. Aubry. 2013. Winter Populations of Douglas' Squirrels In Different-Aged Dougals-Fir Forests. Journal of Wildlife Management 54 (4):577-581.

Buck, S., C. Mullis, and A. Mossman. 1979. A Radio Telemetry Study of Fishers in Northwest California. Arcata, CA: Humboldt State University. 
Callas, R. L., and P. Figura. 2008. Translocation Plan for the Reintroduction of Fishers (Martes pennanti ) to Lands Owned by Sierra Pacific Industries Lands in the Northern Sierra Nevada of California. California Department of Fish and Game. 80 pp.

Carey, A. B., M. L. Johnson, S. E. Applications, N. May, and U. F. Service. 1995. Small Mammals in Managed, Naturally Young, and Old-Growth Forests. Ecological Applications 5 (2):336-352.

Carroll, C., William J Zielinski, and R. F. Noss. 1999. Using Presence-Absence Data to Build and Test Spatial Habitat Models for the Fisher in the Klamath Region, U.S.A. Conservation Biology 13 (6):1344-1359.

Davis, F. W., C. Seo, and William J Zielinski. 2007. Regional variation in home-rangescale habitat models for fisher (Martes pennanti) in California. Ecological Applications 17 (8):2195-2213.

De'ath, G., and K. E. Fabricius. 2000. Classification and Regression Trees : A Powerful Yet Simple Technique for Ecological Data Analysis. Ecology 81 (11):3178-3192. 
Donovan, T. M., G. Warrington, W. S. Schwenk, and J. H. Dinitz. 2012. Estimating Landscape Carrying Capacity through Maximum Clique Analysis. Ecological Applications 22 (8):120523103325002.

Ewen, J. G., D. P. Armstrong, K. A. Parker, and P. J. Seddon. 2012. Reintroduction Biology 1st ed. Hoboken: Wiley-Blackwell.

Gilbert, J. H. 2000. Impacts of Reestablished Fishers on Bobcat Populations in Wisconsin. Madison, WI: University of Wisconsin-Madison. 79 p. Dissertation.

Hanson, K. 2007. Bobcat: Master of Survival. 1st. ed. Oxford: Oxford University Press.

Higley, M. J., and S. Matthews. 2006. Demographic rates and denning ecology of female Pacific fishers (Martes pennanti) in northwestern California. Hoopa, CA: United States Fish and Wildlife Service and Hoopa Valley Tribe; Preliminary Report. $14 \mathrm{p}$.

Ingram, R. 1973. Wolverine, Fisher, and Marten in Central Oregon. Oregon State Game Commission; Central Region Administrative Report; 73-2. 39 p. 
Jacobson, J. E., J. C. Lewis, and M. C. Snyder. 2003. Assessment of Fisher Habitat in Washington State. Olympia, WA: Washington Department of Fish and Wildlife; Tier 1 Refinement and Tier 2 Final Report. 34 p.

Knick, S. T., J. D. Brittell, and S. J. Sweeney. 1985. Population characteristics of bobcats in Washington state. Journal of Wildlife Management 49 (3):721-728.

Koehler, G. M., and M.G. Hornocker. 1989. Influences of seasons on bobcats in Idaho. Journal of Wildlife Management 53 (1):197-202.

Koehler, G. M., M. G. Hornocker, S. Journal, and N. May. 1991. Seasonal Resource Use among Mountain Lions, Bobcats , and Coyotes. American Society of Mammalogists 72 (2):391-396.

Krohn, W. B., K. D. Elowe, and R. B. Boone. 1995. Relations among fishers, snow, and martens: Development and evaluation of two hypotheses. The Forestry Chronicle 71 (1):97-105. 
Larrucea, E. S., G. Serra, M. M. Jaeger, and R. H. Barrett. 2007. Censusing bobcats using remote cameras. Western North American Naturalist 67 (4):538-548.

Lewis, J. C., and G. E. Hayes. 2004. Feasability Assessment for Reintroducing Fishers to Washington. Olympia, WA: Washington Department of Fish and Wildlife; Final Report. 70 p.

Lewis, J. C., C. W. N, P. J. Happe, O. N. Park, E. P. Ave, P. Angeles, O. F. Station, and D. J. Manson. 2011. Olympic Fisher Reintroduction Project : Progress Report 2008-2011. Olympia, WA: Washington Department of Fish and Wildlife; 1-18.

Lewis, J. C., R. A. Powell, and William J Zielinski. 2012. Carnivore Translocations and Conservation: Insights from Population Models and Field Data for Fishers (Martes pennanti). PLOS ONE 7 (3):e32726.

Litvaitis, J. a., J. P. Tash, and C. L. Stevens. 2006. The rise and fall of bobcat populations in New Hampshire: Relevance of historical harvests to understanding current patterns of abundance and distribution. Biological Conservation 128 (4):517-528. 
Long, R. a, T. M. Donovan, P. MacKay, William J Zielinski, and J. S. Buzas. 2010.

Predicting carnivore occurrence with noninvasive surveys and occupancy modeling. Landscape Ecology 26 (3):327-340.

MacKenzie, D. I., J. D. Nichols, G. B. Lachman, S. Droege, J. Andrew Royle, and C. a Langtimm. 2002. Estimating site occupancy rates when detection probabilities are less than one. Ecology 83 (8):2248-2255.

Mcdonald, P., C. Nielsen, T. Oyana, and W. Sun. 2008. Modelling habitat overlap among sympatric mesocarnivores in southern Illinois, USA. Ecological Modelling 215 (4):276-286.

Moruzzi, T. L., T. K. Fuller, R. M. Degraaf, R. T. Brooks, T. L. Moruzzi, T. K. Fuller, R. M. Degraaf, and R. T. Brooks. 2002. Assessing remotely triggered cameras for surveying carnivore distribution. Wildlife Society Bulletin 30 (2):380-386.

Muñoz, J., and Á. M. Felicísimo. 2004. Comparison of statistical methods commonly used in predictive modelling. Journal of Vegetation Science 15 (2):285. 
Neale, J. C. C., and B. N. Sacks. 2001. Resource utilization and interspecific relations of sympatric bobcats and coyotes. Oikos 94, Fasc. 2, 236-249.

Nielsen, C. K., and A. Woolf. 2003. Dispersal of Juvenile Male Bobcats ( Lynx rufus ) in Southern Illinois. Transactions of the Illinois State Academy of Science 96 (4):313-318.

Ohmann, J. L., M. J. Gregory. 2002. Predictive mapping of forest composition and structure with direct gradient analysis and nearest neighbor imputation in coastal Oregon, U.S.A. Canadian Journal of Forestry Research 32:725-741.

Powell, R. 1993. The Fisher: Life History, Ecology, and Behavior 2nd ed. Minneapolis: University of Minnesota Press.

Powell, R. A., A. N. Facka, and D. Clifford. 2012. Reintroduction of fishers into the Northern Sierra Nevada of California : Annual Report for 2011. United States Fish and Wildlife Service; 37p. 
Scheller, R. M., W. D. Spencer, H. Rustigian-Romsos, A. D. Syphard, B. C. Ward, and J. R. Strittholt. 2011. Using stochastic simulation to evaluate competing risks of wildfires and fuels management on an isolated forest carnivore. Landscape Ecology 26 (10):1491-1504.

Spencer, W. D., H. Rustigian-Romsos, J. Strittholt, R. Scheller, W.J. Zielinski, and R. Truex. 2011. Using occupancy and population models to assess habitat conservation opportunities for an isolated carnivore population. Biological Conservation 144 (2):788-803.

Stinson, D. W., and J. C. Lewis. 1998. Washington State Status Report for the Fisher. Olympia, WA: Washington Department of Fish and Wildlife; 64 p.

Tucker, S. a, W. R. Clark, and T. E. Gosselink. 2008. Space Use and Habitat Selection by Bobcats in the Fragmented Landscape of South-Central Iowa. Journal of Wildlife Management 72 (5):1114-1124.

Vinkey, R. A. Y. S., M. K. Schwartz, K. S. Mckelvey, K. R. Foresman, K. L. Pilgrim, B. J. Giddings, and E. R. I. C. C. Loeroth. 2006. When Reintroductions are Augmentations: The Genetic Legacy of Fisher (Martes pennanti) in Montana. Journal of Mammalogy 7 (2):265-271. 
Weir, R. D., A. S. Harestad, and R. C. Wright. 2005. Winter Diet of Fishers in British Columbia. Northwest Naturalist 86 (1):12-19.

Zielinski, W J, and N. P. Duncan. 2004. Diets of Sympatric Populations of American Martens ( Martes Americana) and Fishers ( Martes Pennanti ) in California. Journal of Mammalogy 85 (3):470-477.

Zielinski, W., R. L. Truex, G. A. Schmidt, F. V. Schelexer, K. N. Schmidt, and R. H. Barrett. 2004. Home Range Characteristics of Fishers in California. Journal of Mammalogy 85 (4):649-657.

Zielinski, William J, R. L. Truex, A. Gregory, F. V Schlexer, K. N. Schmidt, and H. Barrett. 2004. Resting Habitat Selection by Fishers. Journal of Wildlife Management 68 (3): 475-492.

Zielinski, William J., and T. E. Kucera. 1995. American Marten, Fisher, Lynx, and Wolverine: Survey Methods for Their Detection. Albany, CA: USDA Forest ServicePacific Southwest Research Station; General Technical Report. PSW-GTR-157. 


\section{Appendix}

\section{Wildlife camera survey photographs}

Included is a sampling of some of the photographs taken during the study. The photos were all taken within the Gifford Pinchot National Forest during the summer and fall of 2012. 
Appendix
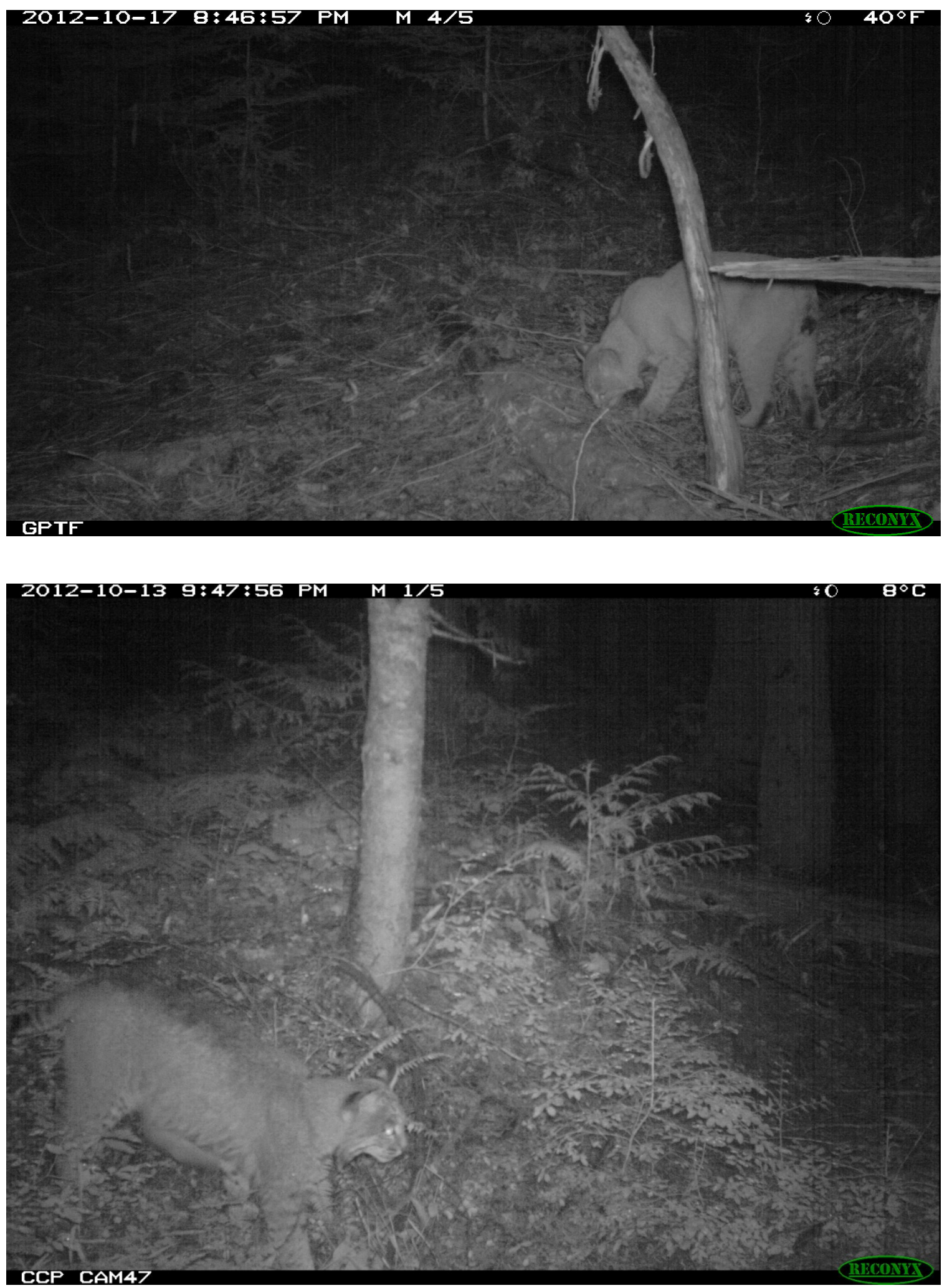
Appendix
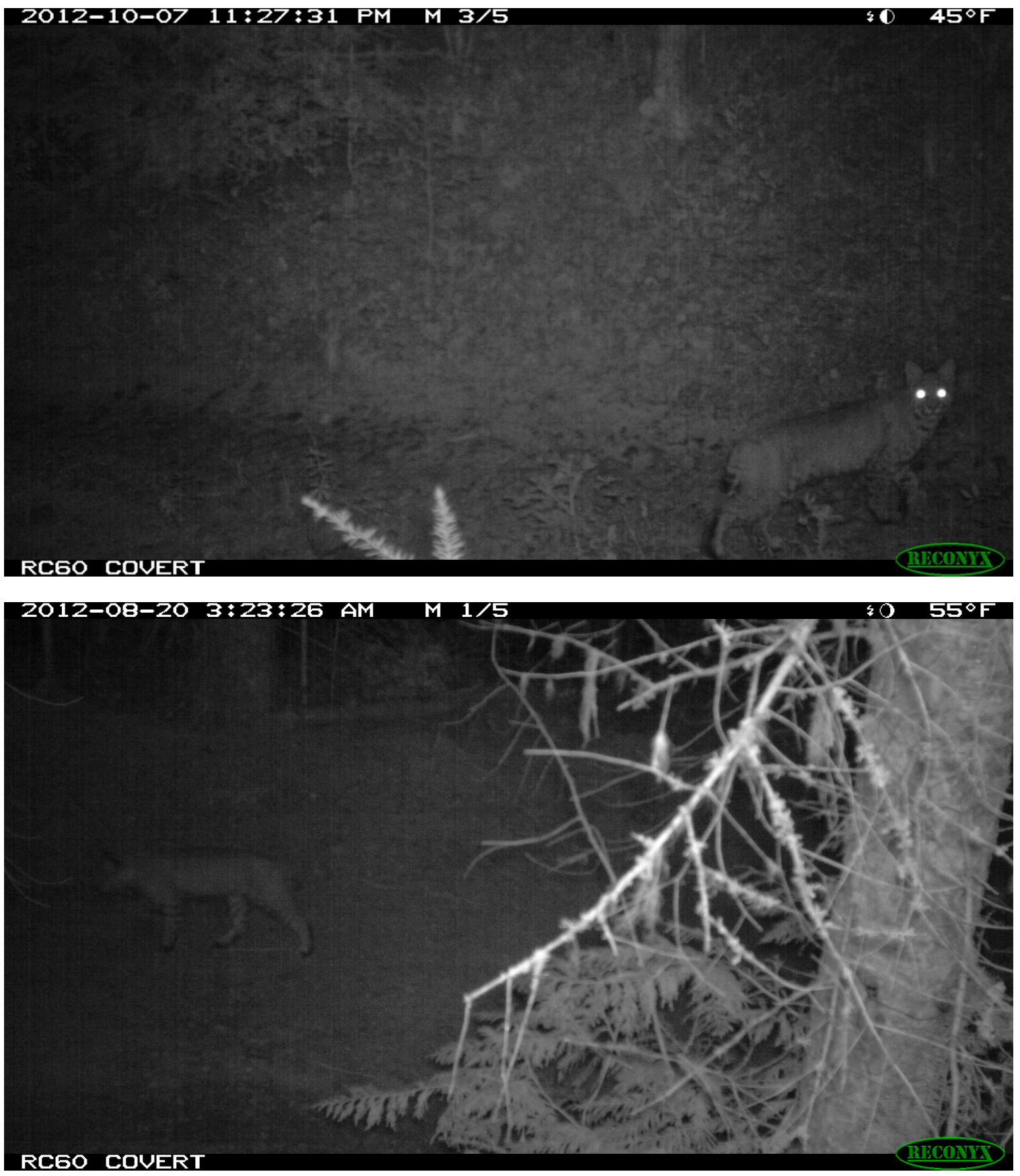
Appendix
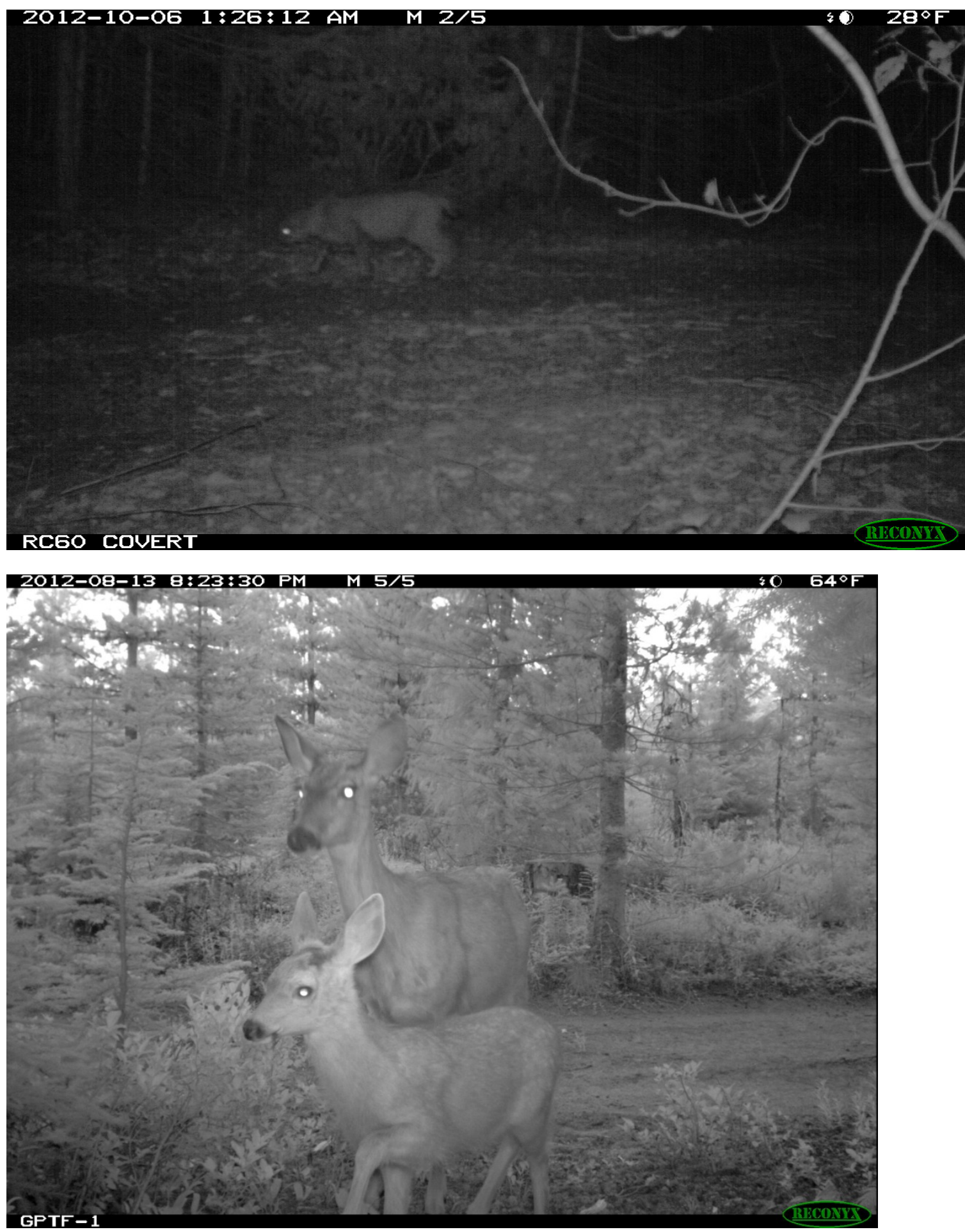
Appendix
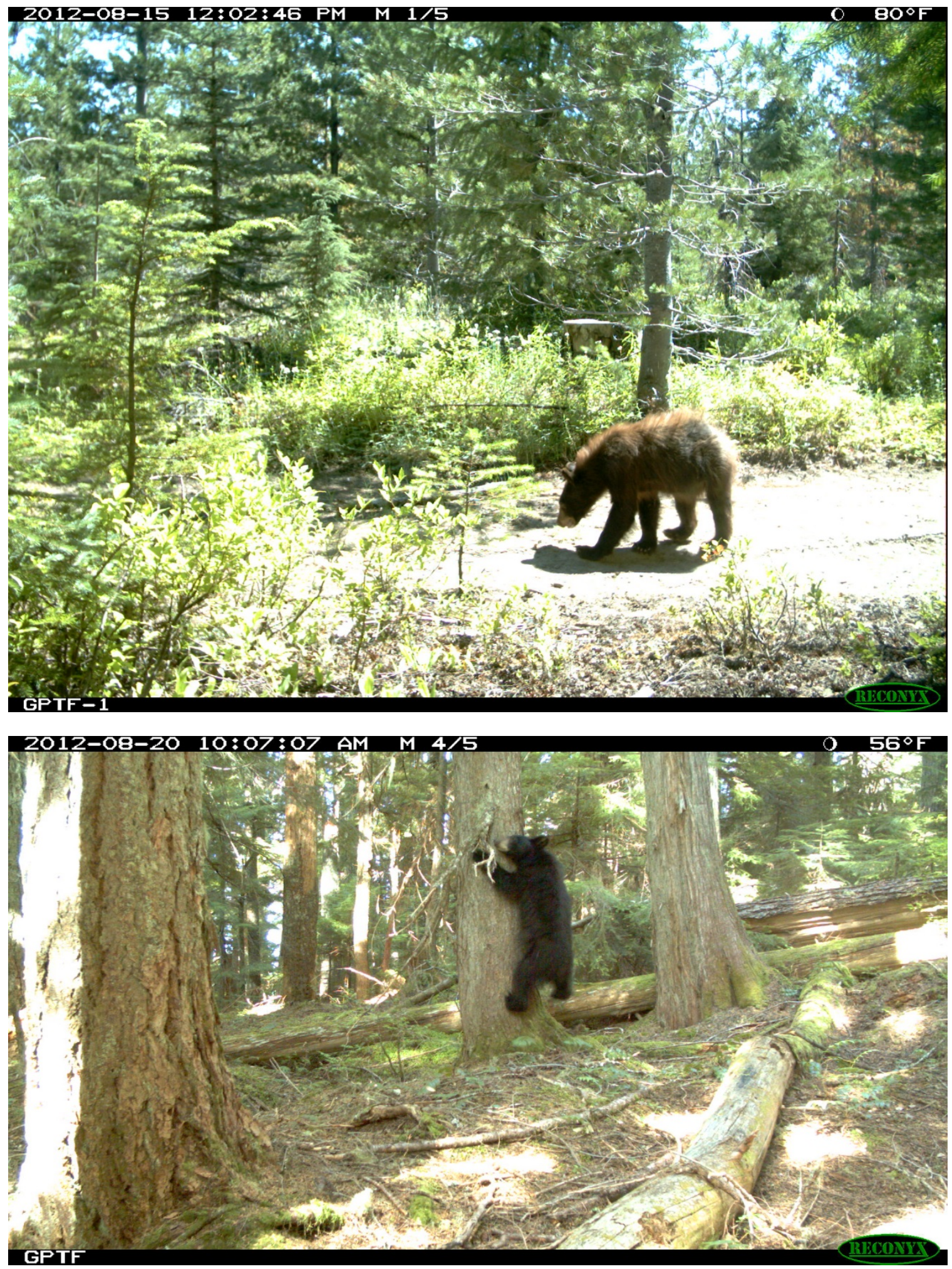
Appendix A
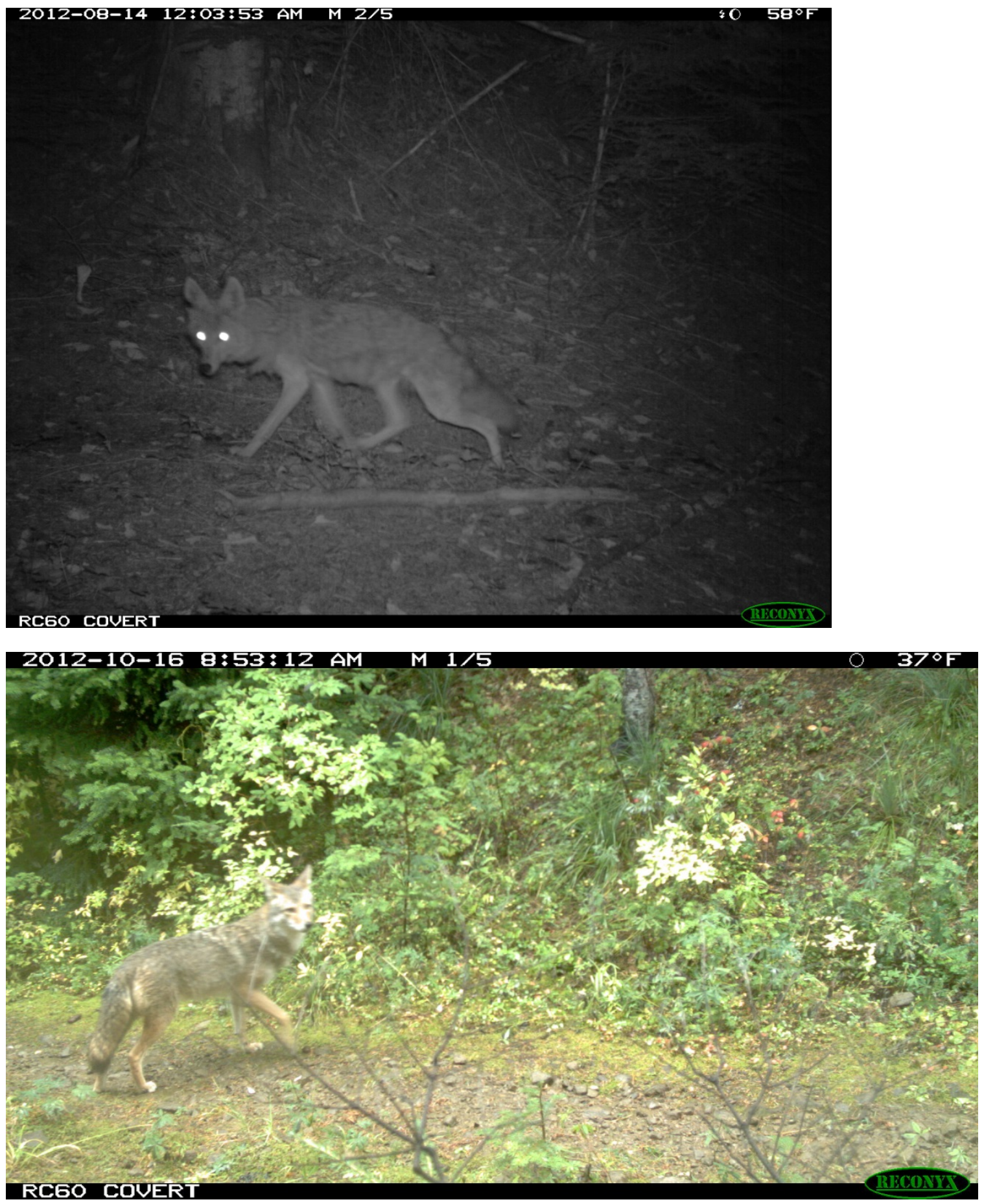